UC-79b

Reporting Date: June 1974 Issued: January 1975

\title{
LASL Ådvanced Plutonium LMFBR Fuel Program Publications
}

by

Joseph A. Le.sry*

*USAEC Division of Reactor Research and Development, Advanced Fuels Systems Branch, Washington, DC 20545 
In the interest of prompt distribution, this LAMS report was not edited by the Technical Information slaff.

Printed in the Unated States of America Available from

National Technical Information Service

U.S Department of Commerce

5285 Port Royal Road

Springtield, VA 2215]

Price Printed Copy \$5.45 Microtiche \$2.25

The report wie propared as an accoust of nork pooneored by the Uarted

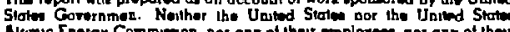

Alamic Energy Comminon. not on of their etrployese not any of then

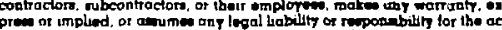

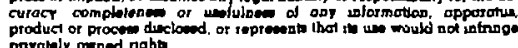

privaluly owned nght 


\section{CONTENIS}

FOREVORD 1

BIBLIOGRAPHY 2

APPEIDIX A 8

Preparation and Properties of Plutonium llononitride and Uranium Mononitride-Plutonium

Mononitride Solid Solutions

APPENUIX B

Plưonium Carbides

APPENDIX C

Differential Thermal Analysis Apparatus for Observation of Refractory Plutonium Compounds

\section{APPERDIX D}

Ceramic Plutonium Fuel Materials Research at Los Alamos Scientific Iaboratory

- NOTICE

This repost was prepared as an account of work sponsored by the United States Government. Neiihr the United States nor the United States Energy Research and Development Adminisiration, nor any of their employees, nor any of their contractors, their employees, not any of their contractors,
subcontractors, or their employees, makes any subcontractors, or their employees, makes any warranty, express or implied, or assumes any legal lability or responsibility for the accuracy, completeness or usefulness of any informaticn, apparatus, product or process disclosed, or represents that its use would not infringe privately owned rights. 
LASL ADVANCED PLUTONIUM LMFBR FUEL PROGRAM PUBLICATIONS

(An annotated bibliography)

by

Joseph A. Leary

\section{ABSTRACT}

Forty articles published by IASL authors are summarized. Subjects include synthesis, rabrication, properties, and irradiation testing of plutonium advanced fuels for fest breeder reactors.

\section{FOREWORD}

A research and development program on plutonium-containing adranced fuels for fast breeder reactors has been in continuous progress since the early 1960's. This report summarizes the articles published in the program with the intent of providing a useful reference for future work. This bib1 iography is arranged in chronological order Some articles on general materials science published by LASL authors have not been included in order to keep the number to a useful minimum and because they do not relate directly to the advanced fuels program.

Many of the details of the work published in these articles are given in progress reports on the advanced fuss program, arid in US/UK Libby-Cockcroft Plutonium Fuels Information Exchange Newsletters as well as in the US/Japan Research Newsletters on Ceramic Nuclear Fuels. Contributions to the High Temperature Fuels Committee Meet- ings also contain additional information. None of these sources has been inciuded in this bibliography, but they are listed here for those interested in seeking details.

The earliest progress reports are titled: Quarteriy Status Report on Solid plutonium

Fuels, and include

$$
\begin{aligned}
& \text { LAMS-2949, Period up to June 30, } 1963 \\
& \text { (First report) } \\
& \text { LAMS-3023, Period July 1-Sept 30, } 1963 \\
& \text { LAMS-3054, Period Oct I-Dec 31, } 1963 \\
& \text { LAMS-3107, Period Jan 1-Mar 31, } 1964 \\
& \text { (Last report in series). }
\end{aligned}
$$

In 1966 a new series appeared under the title Quarterly Reports - Advanced Plutonium Fue1s Program. These are listed below. Quarterly Reports - Advanced Plutonium Fuels Program
LA-3607-MS July 1-Sept 30, 1956
(First report in series)
LA-3650-MS Oct 1-Dec 30, 1956
LA-3686-MS Jan 1-Mar 31, 1967
LA-3745-MS Apr 1-June 30, 1967 


\begin{tabular}{|c|c|}
\hline & July \\
\hline$A-3880-M S$ & Oct $1-\operatorname{Dec} 31,1967$ \\
\hline $1-3933-M S$ & Jan $1-\operatorname{Mar} 31,1968$ \\
\hline$-3993-M S$ & Afr 1 -June 30,1968 \\
\hline$L A-4073-M S$ & July 1 -Sept 30,1968 \\
\hline $4-4114-M S$ & Oct 1 -Dec 31, 1968 \\
\hline$L A-4193-M S$ & Jan 1-Mar 3i, 1969 \\
\hline$L A-4284-M S$ & Apr 1-June 30,1969 \\
\hline \multicolumn{2}{|c|}{ (Third annual report) } \\
\hline LA - $4307-M S$ & July 1 -Sept 30,196 \\
\hline$L, A-4376-M S$ & Oct 1 -Dec 31,1969 \\
\hline LA- $4437-M S$ & Jan 1 -Mar 31,1970 \\
\hline LA- $4494-M S$ & Apr 1 -June 30,1970 \\
\hline$L A-4546-M S$ & July 1 -Sept 30,1970 \\
\hline LA- $4595-M S$ & Oct 1 -Dec 31,1970 \\
\hline LA-4693-MS & Jan 2-Mar 31, 1971 \\
\hline$L A-4749-M S$ & Apr 1-June 30,1971 \\
\hline \multicolumn{2}{|c|}{ (Fifth anrual refort) } \\
\hline LA - $4841-M S$ & July 1 -Sept 30,1971 \\
\hline$L A-4913-P R$ & Oct 1-Dec 31, 1971 \\
\hline$L A-4993-P R$ & Jan 1-Mar 31, 1972 \\
\hline$L A-5067-P R$ & Apr 1 -June 30,1972 \\
\hline$L A-5106-P R$ & July 1 -Sept 30,1972 \\
\hline$L A-5193-P R$ & Oct 1-Dec 3l, 1972 \\
\hline$L A-5284-P R$ & Jan 1-Mar 31, 1973 \\
\hline$L A-5390-P R$ & Apr 1 -June 30,1973 \\
\hline$L A-5477-P R$ & July 1 -Sept 30,1973 \\
\hline$L A-5582-P R$ & Oct 1 -Dec 31,1973 \\
\hline
\end{tabular}

\section{BIBLIOGRAPHY}

1. A. E. Ogard, W. C. Pritchard, R. M. Douglass, and J. A. Leary, "The Powder Metallurgy of plutonium Fuel Materials, " in Power Metallurgy in the Nuclear Age,

Plansee Proceedings 1961, F. Benesovsky, Ed. (Metallwerk Plansee Ag., Reutte/Tyrol, 1962) pp. $364-372$.

- Keviews methods for synthesizing carbides; results on preparation of $\mathrm{PuC}, \mathrm{Pu}_{2} \mathrm{C}_{3}$, and $(\mathrm{U}, \mathrm{Pu}) \mathrm{C}$ by carbothermic reduciion of the oxides; structural analys is by $x$-ray powder diffraction, preparation of dense pellets by cold compaction and siniering in vacuum and helium.

2. A. E. Ogard, W. C. Pritchard, R. M. Douglass, and J. A. Leary, "The Prep- aration of Uranium Monocarbide-Plutonium Monocarbide Solid Solutions, Plutonium Sesquicarbide, and Plutonium Monocarbide," J. Inorg. Nuc1. Chem. 24, 29-34 (1962).

- Synthesis of single phase and mixed phases of carbides by carbothermic reduction of the oxides, followed by fabrication of dense pellets by conventional powder metallurgical methods.

3. Allen E. Ogard and Joseph A. Leary, "Method for Preparing Uranium MonocarbidePlutonium Monocaròide Solid Solution," U.S. Pat. No. 3,082,163, March 19, 1963.

- Carbothermic reduction of mixtures of $\mathrm{UO}_{2}, \mathrm{PuO}_{2}$, and $\mathrm{C}$ to produce single phase (U,Pu)C for fast breeder reactor application.

4. A. E. Ogard, C. C. Land, and I. A. Leary, "The Thermal Expansion of PuC and US-PuC Solid Solutions," J. of Nucl. Materials is, l(1965).

- Thermal expansion between $25^{\circ}$ and $900^{\circ} \mathrm{C}$ and mechanism for contraction in some PuC compositions on heating to $300^{\circ} \mathrm{C}$;

for single phase PuC: $\Delta L / L=\left(-4.0 \times 10^{-4}\right.$ $\left.+8.3 \times 10^{-6} t+3.0 \times 10^{-9} \mathrm{t}^{2}\right)$. (mean coef. $11.0 \times 10^{-6} /{ }^{\circ} \mathrm{C}$ ); for single phase $\mathrm{U}_{0.87} \mathrm{Pu}_{0.13^{\mathrm{C}}}: \Delta \mathrm{L} / \mathrm{L}$ $=\left(-3.8 \times 10^{-4}+8.7 \times 10^{-6} \mathrm{t}\right.$ $\left.+3.0 \times 10^{-9} \mathrm{t}^{2}\right)$ (mean coef. $11.1 \times 10^{-6} /{ }^{\circ} \mathrm{C}$ ).

5. J. A. Leary, R. L. Thomas, A. E. Ogard, and G. C. Wonn, "Thermal Conductivity and Electrical Resistivity of UC, $(U, P u) C$ and PuC," in Carbides in Nuclear Energy, L. E. Russell Ed. (Macmillan and Co. Ltd., London, 1965) p. 365-371.

- Thermal conductivities of PuC, UC, and $(\mathrm{U}, \mathrm{Pu}) \mathrm{C}$ over the temperature range $200-400^{\circ} \mathrm{C}$; reduction of thermal conductivity by addition of PuC to UC, and corresponding effect on electrical resistivity.

6. Joseph A. Leary and Robert L. Nance, "Method of Preparing Plutonium Mononitride," 
U.S. Pat. No. 3,279,898, Oct 18, 1966.

- Describes method of preparing nonpyrophoric plutonium nitride from plutonium metal by conversion to the hydride and reaction with nitrogen.

7. J. A. Leary, "Recent Developments in High-Temperature Plutonium Compounds," Trans. Amer. Nucl. Soc. 9, 37 (1966).

- A review of developments in advanced uranium-plutonium materials, including properties as thernal conductivizy, thermal expansion, phase relationships and structure analysis, thermodynamic properties.

8. J. A. Leary, R. L. Nance, W. C. Fritchard, J. G. Reavis, M. W. Shupe and A. E. Ogard, "Preparation and Properties of Plutrnium Mononitride and Uranium Mononitride Solid Solutions," American Ceramic Society, Portland, Oregon, Oct. 26-28, 1966.

- Methods for preparing subject nitrides as fine powders and as dense pellets; reaction of PuN with $\mathrm{PuO}_{2}$; lattice dimensions of solid sclutions of PuN in UN; differen$t$ ial thermil analysis of nitrides to melting; decomposition pressures of actinide nitrides; Gibbs free energy of formation of PuN at $700^{\circ} \mathrm{K}$ was $(-60 \pm 1) \mathrm{kcal} / \mathrm{mole}$ by emf measurements. (See Appendix A)

9. G. M. Campbell and J. A. Leary, "Thermodynamic Properties of piutonium Mononitride from Electromotive Force Measurements," J. Phys. Chem. 70, 27032705 (1966).

- The sta.'dard free energy of formation of PuN was measured in a pair of emf cells.

10. J. A. Leary, W. C. Pritchard, R. L. Nance, and M. W. Shupe, "Refractory Plutonium Fuel Materiais," in Plutonium 1965, A. E. Kay and M. ‥ Waldroli, Eds. (Chapman and Ha11, London 1965) pp. 639-653.
- Synthesis of PuC, $\mathrm{Pu}_{2} \mathrm{C}_{3}$, and $(\mathrm{U}, \mathrm{Pu}) \mathrm{C}$ powders and fuel pellet fabrication reaction of PuN with $\mathrm{PuO}_{2}$ to form $\mathrm{Pu}_{2} \mathrm{O}_{3}$ and $\mathrm{N}$; solid solubility of PuO in PuN.

11. J. L. Green, G. P. Arnold, J. A. Leary, and N. G. Nereson, "A Low Temperature Magnetic Transition in Patonium Monocarbide," J. Nucl. Materials 23, 231-232 (1967).

- Low temperature neutron diffraction indicated an antiferrcmagnetic transition at $100^{\circ} \mathrm{K}$.

12. J. G. Reavis, M. W. Shupe, C. W. Bjorklund, and J. A. Leary, "Phase Relations in the High-Carbon Portion of the U-Pu-C System," Trans. Amer. Nucl. Soc. 10, 111 (1967).

- High-temperature differential thermal analysis study of $(\mathrm{U}, \mathrm{Pu})_{2} \mathrm{C}_{3}$ and $(U, P u) C_{2}$ compositions; $x$-ray powder diffraction, metallographic, and electron microprobe analyses; $\mathrm{U}_{2} \mathrm{C}_{3}$ and $\mathrm{Pu}_{2} \mathrm{C}_{3}$ form solid solutions over wide range of composition; UC, and $\mathrm{PuC}_{2}$ form wide range of solid solutions; transition temperatures for $\mathrm{M}_{2} \mathrm{C}_{3}+\mathrm{C}=2 \mathrm{MC}_{2}$; melting of $\mathrm{Pu}_{2} \mathrm{C}_{3}$ at $1980^{\circ} \mathrm{C}$, melting of $\mathrm{MC}_{2}$ at $2425^{\circ} \mathrm{C}$ for $\mathrm{U}_{0.8} \mathrm{Pu}_{0.2} \mathrm{C}_{2}$.

13. J. L. Green, G. P. Arnold, J. A. Leary, and N. G. Nereson, "Crystallography and Magnetic Ordering in Plutonium Carbides by Neutron Diffraction," Bu11. Amer. Ceram. Soc. 46, 89s(1967).

- Low temperature neutron diffraction study of $\mathrm{PuC}$ and $\mathrm{Pu}_{2} \mathrm{C}_{3}$.

14. C. W. Bjorklund, R. M. Douglass, and J. A. Leary, "Self-Irradiation Damage in Plutonium Ceramics," Bull. Amer. Ceram. Soc. 46, $901(1967)$.

- The lattice dimensions of various compounds including $\mathrm{PuO}_{2}, \mathrm{PuN}$, and several $\mathrm{Pu}$ carbides were determined after storage in the $-200^{\circ}$ to $+400^{\circ} \mathrm{C}$ range. Dose rates were varied by increasing the ${ }^{23}{ }^{3} \mathrm{Pu}$ isotopic abundance. 
15. G. M. Campbe11, L. J. Mullins, and J. A. Leary, "Thermodynamic Properties of Plutonium Compounds by EMF Techniques," Thermodynamics of Nuclear Materials, 1967, (International Atomi: Energy Agency, Vienna 1968) pp. 75-88 (no editors).

- Measurements on properties of PuC1 $1_{3}$ PuN, PuRu, PuC, and $\mathrm{Pu}_{2} \mathrm{C}_{3}$ over temperature range $950^{\circ}-110^{2} 0^{\circ} \mathrm{K}$;

for the reaction: $2 \mathrm{Pu}(\mathrm{l})+3 \mathrm{C}(\mathrm{s})=$

$+\mathrm{Pu}_{2} \mathrm{C}_{3}(\mathrm{~s})-\Delta \mathrm{G}_{\mathrm{T}}^{\circ}=52.5-0.6147 \mathrm{~T}$

$\mathrm{kcal} / \mathrm{mole}$;

for the reaction: $\mathrm{Pu}(l)+(1-\mathrm{x}) \mathrm{C}(\mathrm{s})=$

$$
\begin{aligned}
& +\operatorname{PuC}_{(1-x)}(\mathrm{s})-\Delta \mathrm{G}_{\mathrm{T}}^{0} \\
& =17.2-0.0023 \mathrm{~T} \mathrm{kca} 1 / \mathrm{mole} .
\end{aligned}
$$

16. J. A. Leary and A. E. Ogard, "Plutonium Carbides," chapzer for unpublished Reactor Materials Handbook No. 3. (See Appendix B)

- Review article with properties, etc.

17. J. A. Leary and K. W. R. Johnson, "Thermal Conductivity of Uranium-Plutonium Carbide Fuels," in Int. Symp. on Plutonium Fuels Technology, K. E. Horton, R. E. Macherey, and R. J. A11io, Eds. (A.I.M.E., New York, N.Y. 1968) pp. 309-321.

- Thermal conductivities and thermal diffusivities of UC, PuC, and $(\mathrm{U}, \mathrm{Pu}) \mathrm{C}$; effects of sample porosity, stoichimetry, temperature, impurities, and solid solution formation.

18. J. G. Reavis, J. Buchen, and J. A. Leary, "Differential Thermal Analysis Apparatus for Observation of Refractory Plutonium Compounds." (See Appendix C)

- Describes apparatus for measuring melting points and temperatures of crystallographic transitions for plutonium compounds in $1000^{\circ}$. $2440^{\circ} \mathrm{C}$ range.

19. K. W. R. Johnson and J. A. Leary, "The Thermal Conductivity of Uranium-Plutonium Carbides," Trans. Amer. Nuc1. Soc. 12, pp. 591-592 (1969).
- Thermal conductivity and porosity effects over temperature range

$$
\begin{aligned}
& 100^{\circ}-1000^{\circ} \mathrm{C} \\
& K_{p}=(a+b T)\left(\frac{1-P}{1+\beta P}\right) \\
& \text { where } T=\text { temperature in }{ }^{\circ} \mathrm{C} \\
& a=0.0394 ; b=2.53 \times 10^{-5} \\
& B=1.01 \\
& P=\text { pore fraction } \\
& K_{p}=\text { conductivity in cal/sec cm }{ }^{\circ} \mathrm{C}
\end{aligned}
$$

20. J. A. Leary, M. W. Shupe, R. Honnell, and A. E. Ogard, "Synthesis and Fabrication of Carbide Fuels, Trans. Amer. Nuc1. Soc. 12, pp. 577-578 (1969).

- Synthesis and fabrication of single phase (U, $\left.P_{U}\right) C$ fuel for properties and irradiation testing; review of U.S. processes.

21. J. A. Leary, "Present Status of the Uranium-Plutonium-Carbon Phase Diagram," Ceramic Nuclear Fuels, Owen L. Kruger and A. I. Kaznoff, Eds. Proceedings of the International Symposium on Ceramic Nuclear Fuels, (Amer. Ceramic Soc., Special Publication No. 2, 1969) pp. 38-50.

- Phase diagrams and structure analysis for the U-Pu, the U-C, and the Pu-C systems; phase relationships in the U-Pu-C system over wide range of composition and temperature; no ternary compounds.

22. R. A. Kent and J. A. Leary, "Mass Specrometric Studies of Plutonium Compounds at High Temperatures. IV. The Vaporization of PuN," J. of High Temp. Sci. 1, 176-183 (1969).

- The monoritride vaporizes congruently to the elements;

$$
\begin{aligned}
& \log P_{\mathrm{Pu}}(a t m)=(6.445 \pm 0.055) \\
& -(21,958 \pm 98) / \mathrm{T}{ }_{\mathrm{K}} \\
& \Delta H^{\circ} \mathrm{F} 298=-71.2 \pm 2.5 \mathrm{kcal} / \mathrm{mole} \\
& \Delta 5^{\circ}=-19.9 \pm 2.0 \mathrm{e} . \mathrm{u} .
\end{aligned}
$$

23. J. A. Leary and R. A. Kent, "Ceramic Plutonium Fuel Materials Research at* Los Alamos Scientific Laboratory," talk pre- 
sented at Japan Atomic Energy Research Inst., Tokai-Mura, Japan, Sept 1969.

- Description of LASL Advanced Fuels Progam; summary of important results to date; mean linear thermal expansion of $\mathrm{Pu}_{2} \mathrm{C}_{3}$ over the temperature range $20^{\circ}-1600^{\circ} \mathrm{C}$ was $15.6 \mathrm{x}$ $10^{-6} /{ }^{\circ} \mathrm{C}$; mean linear thermal expansion of $\mathrm{PuC}_{2}$ over the range $1750^{\circ}-2000^{\circ} \mathrm{C}$ was $21 \times 10^{-\circ} /{ }^{\circ} \mathrm{C}$; neutron diffraction studies on $2{ }^{\circ} \mathrm{PuC}$ and $2{ }^{4}{ }^{\circ} \mathrm{Pu}_{2} \mathrm{C}_{3}$ at $20-100^{\circ} \mathrm{K}$; structural analysis of $\mathrm{Pu}_{2} \mathrm{C}_{3}$ and $\mathrm{U}_{2} \mathrm{C}_{3}$; differential thermal analysis on $(\mathrm{U}, \mathrm{Pu}) \mathrm{O}_{2},(\mathrm{U}, \mathrm{Pu}) \mathrm{C}$, and $(\mathrm{U}, \mathrm{Pu}) \mathrm{C}_{2}$; thermochemical properties of $\mathrm{PuCl}_{3}$, $\mathrm{PuN}, \mathrm{Pu}_{2} \mathrm{C}_{3}, \mathrm{PuC},(\mathrm{U}, \mathrm{Pu}) \mathrm{C}$, and $(\mathrm{U}, \mathrm{Pu}) \mathrm{O}_{2}^{2}{ }^{3} \quad$ (See Appendix D)

24. M. Tokar, A. W. Nutt, and J. A. Leary, "Mechanica1 Properties of Carbide and Nitride Reactor Fuels," Trans. Amer. Nuc1. Soc. 12, 592-293 (1969).

Creep measurements on $\mathrm{U}_{0.8} \mathrm{Pu}_{0.2}$ from $1200^{\circ}-1600^{\circ} \mathrm{C}$ and $2000-600^{\circ}$ psi; elastir: moduli at foom temperature by ultrasonic pulse echo and mode ccinversion technique.

25. A. E. Ogaril, J. G. Reavis, and J. A. Leary. "Characterising the HighTemperature Thermophysical and Thermochemical Properties of Irradiated Fue1s - Present Status and Future Needs," Proceedings of the 16th Coj.f. on Remote Systems Tech. (1969).

- Describes equipment for use in hot cell tc determine high temperature heat content and high temperature differential analysis; indicates some future requirements and problem areas such as micro scale measurements of properties.

26. G. M. Campbe11, "Thermodynamic properties of Plutonium Nitrides by Galvanostatic Potential Determination," J. Phys. Chem. 73, 350-355(1969).

- Describes equipment and technique for determining thermodynamic properties of materials; for the

\section{reaction}

$\mathrm{Pu}(\mathrm{l})+0.5 \mathrm{~N}_{2}(\mathrm{~g})=\operatorname{PuN}(\mathrm{s})$.

The free energy of formation of

PuN is given by

$-\Delta G_{T}^{0}=73.8-0.0225 T_{{ }_{K}} \mathrm{kcal} / \mathrm{mole}^{\mathrm{e}}$

and

$-\Delta \mathrm{H}_{29 \mathrm{~g}}^{\circ}=72.5 \mathrm{kcal} / \mathrm{mole}$.

27. G. M. Campbe11, R. A. Kent, and J. A. Leary, "Thermodynamic Properties of the Plutonium-Carbon System," in Plutonium 1970 and Other Actinides, William $N$. Miner, Ed. (A.I.M.E. New Zork, N.Y., 1970) pp. 781790 .

- Thermochemical data by mass spectrometer-Knudsen cell and by emf methoris over the range $900-2200^{\circ} \mathrm{K}$ and composition raage $\mathrm{Pu}$ to $\mathrm{PuC}+\mathrm{C}$; standard heats and entropies of formation for $\mathrm{PuC}_{0.9}, \mathrm{Pu}_{2} \mathrm{C}_{3}$, and $\mathrm{PuC}_{2}$.

28. J. G. Reavis, K. A. Johnson, and J. A. Leary, "MeIting Behavior of (U,Pu) Monocarbides," in Plutonium 1970 and Other Actinides, William N. Miner, Ed. (A.I.M.E. New York, N. Y., 1970) pp. 791-798.

- Solidus and liquidus temperatures for $(U, P u) C$ solid solutions from 0-50 mol\% PuC by DTA and metallography. Solidus and 1 iquidus of UC- 20 PuC were 2275 and $2485^{\circ} \mathrm{C}$, respectively.

29. R. A. Kent, "Mass Spectrometric Studies of Plutonium Compounds at High Temperatures V. The Plutunium-Carbon System," in Recent Developments in Mass Spectroscopy Koreichi Ogata and Teruo Hayakawa, Eds. (University of Tokyo Press, 1970) pp. 11241131 .

- There are three regions of the Pu-C system which give rise to invariant but not congruent vaporization $\left(\mathrm{PuC}+\mathrm{Pu}_{2} \mathrm{C}_{3}, \mathrm{Pu}_{2} \mathrm{C}_{3}+\mathrm{C}\right.$, and $\mathrm{PuC}_{2}+\mathrm{C}$ ); the sesquicarbide has a range of homogeneity at $1550^{\circ} \mathrm{C}$; transition of $\mathrm{Pu}_{2} \mathrm{C}_{3}$ to $\mathrm{PuC}_{2}$ occurs at $1660^{\circ} \mathrm{C}$; standard heat and 
entropy of formation for PuC and $\mathrm{Pu} \mathrm{C}_{3}$.

30. J. L. Green, G. P. Arnold, J. A. Leary, and N. G. Nereson, "Crystallography and Magnetic Ordering Studies of Plutonium Carbides Using Neutron Diffraction," J. of Nuc1. Mater. 34, 281-289 (1970).

- Low temperature neutron diffraction measurements on $\mathrm{PuC}$ and $\mathrm{Pu}_{2} \mathrm{C}_{3}$; magnetic transition in PuC at $100^{\circ} \mathrm{K}$; no magnetic ordering found in $\mathrm{Pu}_{2} \mathrm{C}_{3}$; magnetic unit cell of PuC and parameters for $\mathrm{Pu}_{2} \mathrm{C}_{3}$.

31. J. A. Leary, A. F. Ogard, M. W. Shupe, and J. O. Barner, "Synthesis, Fabrication, and Behavior of Single Phase U-PuCarbides for Fast Breeder Reactors," in proc. Intern. Mtg. on Fast Reactor Fuel and Fuel Elements, M. Dalle Donne, K. Kummerer, K. Schroeter, Eds. (Gesellschaft fuer Kernforschung, Karlsruhe, Germany, 1970) pp. 436-453.

- Processing of powders and pellets of various densitios and enrichments, thermal redistribution of $\mathrm{Pu}$ in mixed two-phase carbides, fabrication of $\mathrm{Na}$-bonded pins, irradiation program design, electron microprobe studies on unirradiated fueI.

32. J. G. Reavis and J. A. Leary, "Differential Thermal Analysis Observations of (U,Pu) Dicarbides," in Plutonium 1970 and Other Actinides, William N. Miner, Ed. (A.I.M.E. New York, N.Y., 1970) pp. 809-817.

- Results on $\mathrm{UC}_{2}-\mathrm{PuC}_{2}$ pseudobinary over ت̈u11 range of composition, with $x$-ray diffraction and metallographic supplemental studies, structures and transition temperatures in the range $1000^{\circ} \mathrm{C}$ to $2500^{\circ} \mathrm{C}$.

33. J. L. Green and J. A. Leary, "Ihermal Expansion and Phase Equilibria of the Carbon-Saturated Plutonium Carbides," J. App1. Physics 41, 5121-5124(1970).

- Description of high temperature diffractometer; mean linear thermal expansions of $\mathrm{Pu}_{2} \mathrm{C}_{3}$ and $\mathrm{PuC}_{2}$ (fcc).
34. J, G. Reavis, G. R. Brewer, D. B. Court, and J. W. Schulte, "A Differential Thermal Analysis Appa:atus for Observation of Irradiated Pu-Containing Reactor Fuels," Proceedings of the 19 th Conf. on Remote Systems Technology pp. 112-117 (1971).

- Description of hot-ce11 apparatus and results on irradiated $(U, P u) O_{2}$; later used for irradiated $(\mathrm{U}, \mathrm{Pu}) \mathrm{C}^{2}$.

35. M. Tokar and J. A. Leary, "Compressive Creep and Hot Hardness of UraniumPlutoniun Carbide," 73ró Annual Mtg. of the Amer. Ceram. Soc., Apr 1971 (see laver reference of same title).

36. J. A. Leary, "Nuclear Fuels Work in the U.S.," talk at Karlsruhe Nuclear Research Center, Karlsruhe, Germany (Nay 1971).

37. J. O. Barner, "Behavior of SodiumBonded (I,Pu)C Fuel Elements After Moderate Burnup," Fast Reactor Fuel Element Techno1ogy, Ruth Farmakes, Ed. (Interstate Printers, Danville, I11., 1971), pp. 819-848.

- Results of irradiation of $(U, P u) C$ fuel in annealed type 316 stainless steel clad at $30 \mathrm{~kW} / \mathrm{ft}$ to burnups of 3.7 and 5.0 atom 8 without failure.

38. J. C, C1ifford, "Thermal Neutron Irradiation of Sodium-Bonded Solid Solution (U,Pu)C Fue1," Los A1amos Scientific Laboratory report LA-4951 (February 1973).

- Irradiation of small samples with fuel surface temperature of $730^{\circ} \mathrm{C}$, maximum fower density of $760 \mathrm{~W} / \mathrm{g}$, and maximum burnup of 13 atom possible evidence for plutonium metal reaction with noble metal fission products such as ruthenium, palladium, rhodium and with silicon.

39. Michael Tokar, "Compressive Creep and Hot Hardness of U-Pu Carbides," J. Aner. Ceram. Soc. 56, 173-177 (1973).

- Compressive creep of $\mathrm{U}_{0.79} \mathrm{Pu}_{0.22}$ $C_{1.02}$ was studied at $1300^{\circ}-1500^{\circ} \mathrm{C}$ and 2000-6000 psi

$\varepsilon=7.96 \times 10^{4} \sigma^{2.44}$ 
$\exp (-126.4 \mathrm{kcal} / \mathrm{ml} / \mathrm{RT})$

wheie $\dot{\varepsilon}=$ creep rate, per hour

$\sigma=s t r e s s, p s i$

$T=$ temperature, ${ }^{\circ} \mathrm{K}$

The hardnesse: of monocarbides with various $\mathrm{Pu} / \mathrm{U}$ ratios were measured over the ranga $25-1200^{\circ} \mathrm{C}$. Merhanisms are discussed.

40. M. Tosar and J. L. Creen, "Hot
Hardness Testing of Uranium-Plutonium Ceramics," The Science of Hardness Testing and Its Research Applications, J. H. West brook and H. Conrad, Eds., Amer. Soc.

Metals, Metals Park, Ohio (1973) pp. 241248.

- Results from References 24, 35 and 39 plus new data on PuN. 


\title{
PREPARATION AND PROPERTIES OF PLUTONIUM SOSONTTRE ALD TRANTUM MONONTTRIDE-PLUTONIUM MONONTREE SOLD SOLUTIONS
}

\author{
by
}

J. A. Leary, R. L. Nance, W. C. Pritchard, J. G. Reavis, M. W. Shupe, and

\author{
A. E. Ogard
}

Riniversity of Californin, Los Alamos Scientific Laboratory, Los Alamos. New Mexico, U.S.A.)

Mononitrides of uranium and plutonium have potential advantages as nuclear fuels. Metal atom density, meltin\& point. thermal coiatuctivity, and compatibility with economic fuel clad appear to be favorable in comparison to other fuels.

Uranium mononitride powders have been synthesized by reac:ion of uranium hydride with nitrogen to form uranium segquinitride. followed by thermal decom position of the sesquinitride to form singlt phase, stoichiometric uranium mononitride. Plutonium mononitride is the only compound known in the plutonium nitrogen system. Powders of monophaslc plutonium nitride were prepared directly by reaction of plutonium hydride with nitrogen at $800^{\circ}$. Solid solutions of plutonium mononitride in uranium mononitrides were prepared by sintering mixtures of the individual mononitride powders.

Dense pellets of single phase uranium mononitride, plutonium mononicide. Ind solid solution mononitrides have been produced by cold compaction and sinter ing in the $1600^{\circ}-1900^{\circ}$ temperature range. The effects of fabrication variables suct: as particle size range of the powders. pressing pressure, and sintering conditione on pellet denaity and integrtty are reported.

The dimension of plutonium mononitride crystal lattice is independent of the equilibration temperature. up to the melting point, and is independent of the nitrogen partial pressure up to a pressure of one atmosphere, Plutonium mononitride is isostructural aith F.C.C. uranium mononitride. and the two compounds forin a continuous serles of solid solutions over the entire range of composition. The lattice dimension increases unlformly from 4.8892 for pure uranium mononitride to $4.9048:$ for pure plutonium mononitride. Regandless of sintering temperature, the lattice parameters display slightly negative deviations from Vegard's law for compositions contatring less than 50 percent plutonium mononitride. and slightly positive deviations for greater than 50 percent flutonium mononitride. 
Thermsl decomposition of mononitrides occurs in the temperature range $\sim 2500^{\circ} \mathrm{C}$. The thermal stability of the mononitrides as a function of tamperature and nitrogen pressure are discussed and compered with that of cxide and carbidc fuels. Other properties of interest to nuclear fuel applications such as thermal expansion. thermai conductivity, and thermodynamic properties. are compared with thuse of other potential iast breeder reactor fuels. 
APPENDIX B

\title{
PLLTONILA CARBDES
}

\author{
J.A. Leary and A.E. Ogard
}

Los Alamos Scientific Laboratory

\section{Preuaration:}

Methods which have bien used in the preparation of the plutomum carbides are direct are melting of plutomium and graphite, $(1,2,3,4,5,6)$ carlon reduction of $\mathrm{PuO}_{2}$ at $1100-1450^{\circ} \mathrm{C}_{0}^{(1,7,9,9,10,11,12)}$ sintering of mixtures of carbon powder and plutoniun metal or plut aium hydride powder at temperatures up to $1400^{\circ} \mathrm{C},(7,13,14)$ and reaction of hydrocarbons with plutonium at $600-500^{\circ} \mathrm{C} .^{(15)}$ Each method of preparation has advantiges. Arc melting produces a dense carbide that is essentially free of oxygen and nitiogen impurities. However, the composition is difficult to control and the product is inhomogeneous unless extensive hent treatment is performed. This is especially true of the monocarbide. Carbon reduction of $\mathrm{PuO}_{2}$ is a consistent and ecuomical procedure. It is difficult, uhough, . pacpare single phase $\mathbf{P u C}_{1-x}$ and impussible to eliminate completcly all of the oxygen. Single phase $\mathrm{PuC}_{1-\mathrm{x}}$ of controlled carlon content can readily ba prepared by sintering a mixture of graphite powder and plutonium hydride powder. An inert gas atmosphere glove box is necessary for this procedure since the plutonium hydride is pyrophoric. Even with the use of an inert gas atmosphere most carbides that are made from powders contain up to $1000 \mathrm{ppm}$ of oxygen.

\section{Phase Relationships:}

The phase diagram of the plutumium-earibon system first proposed by Mulford et al. (1) Figure 1 is basically the proposed diagram modified by more recent results. ${ }^{(29)}$ Four carbide compounds have been identified: the zeta-phase at $\mathrm{Pu}_{3} \mathrm{C}_{2}$, a carbon deficient $\mathrm{PuC}_{1-\mathrm{x}}, \mathrm{Pu}_{2} \mathrm{C}_{3}$, and the high temperature phasc, $\mathrm{PuC}_{2}$.

The transformation temperatures of the six plutonium allotropes do 


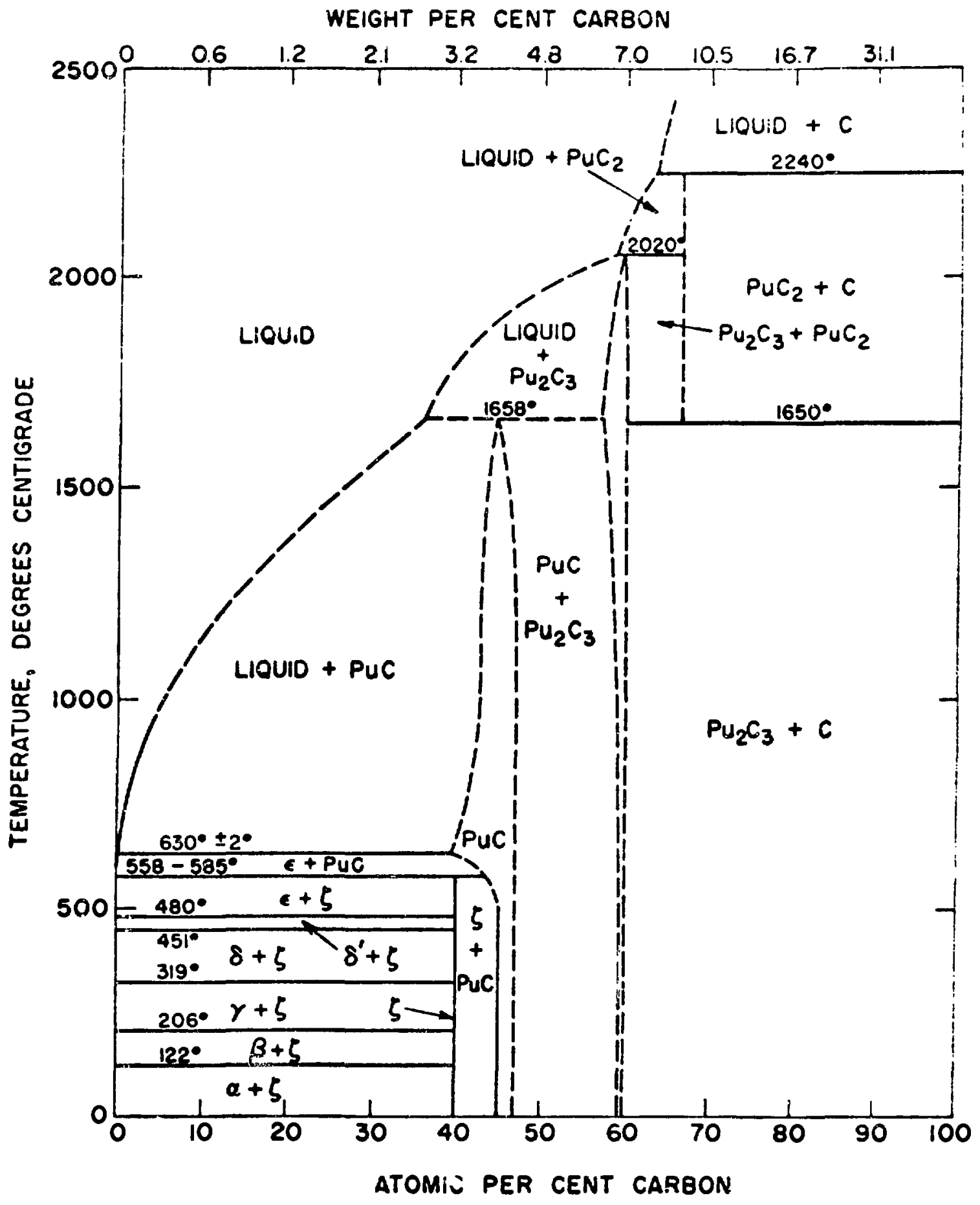


nut aprear to be affected by the dissolution of carbon. (1, 16) The melting point of plutonium is lowered by up to $s^{n} \cdot(1, i)$ Above this cutectic the solubilaty of carbon in liquid plutonium can be expressed by the equation $\log _{1:}$ atom fraction carbon $=0.50-2.3 \times 10^{3} / \mathrm{T}\left(700-950^{\circ} \mathrm{K}\right) .^{(17)}$

The structurc of $\mathrm{Pu}_{3} \mathrm{C}_{2}$ has not been cietermined but appears to be lated to that of $\mathrm{PuC}_{1-\mathrm{x}}$. X-ray pouder diffraction patterns of the $\mathrm{Pu}_{3} \mathrm{C}_{2}$ phase have been described by several authors. $(1,6,18) \quad \mathrm{Pu}_{3} \mathrm{C}_{2}$ decomposes by a peritectoid reaction to $\epsilon-P u+P u C_{1-x}$ in the range of $558-585^{\circ} \mathrm{C} .(1,6,18)$

Plutonium monocarbide has the fec NaCl-type structure. ${ }^{(19)}$ It is a non-stoichiometric compound that is deficient in carbon, and has a composition range of homogeneity as shown in Table 1 . The room temperature lattice parameter increases from a value of 4.953 to $4.973 \mathrm{~A}$ as the carbon content is increased from the hypo- to the hyperstoichiometric composition. $(1,6,7,20,21)$ The lattice parameter increases slowly with time owing to self-irradiation damage of the latice. ${ }^{(21,24,25)}$ The high solubilities of oxygen and nitrogen in $\mathrm{PuC}_{1-\mathrm{X}}$, also cause wide variations in lattice dimension. $(22,23)$ An antiferromagnetic transition

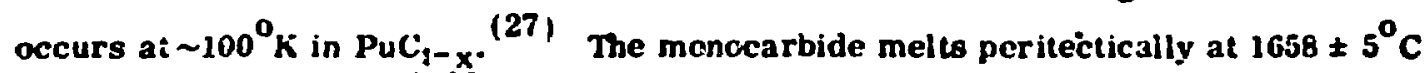
to form liquid $+\mathrm{Pu}_{2} \mathrm{C}_{3} \cdot(1,26)$

The structure of $\mathrm{Pu}_{2} \mathrm{C}_{3}$ is body centered cubic. (28) A small variation in lattice parameter has been found suggesting a small range of composition: 8.126 - R. 132 . $^{(1)} 8.129 .^{(7)} 8.131-8.234$, $^{(10)}$ and $8.121-8.126 .^{(20)}$ volume Iraction andysis of heat treated $\mathrm{PuC}+\mathrm{Pu}_{3} \mathrm{C}_{3}$ samples show a lower phase boutklary

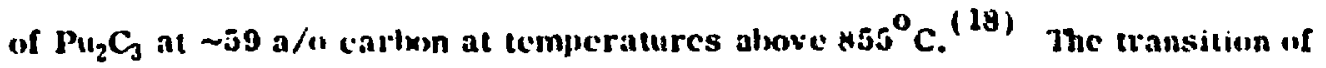

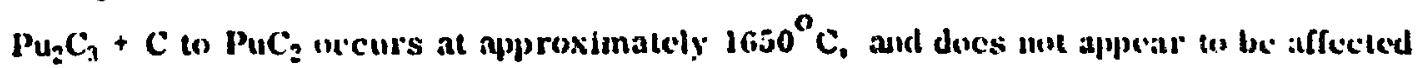
by the carbon concentration. (29) peritectic melting of $\mathrm{Pu}_{2} \mathrm{C}_{3}$ lo liquid + PuC aecurs at $2020=40^{\circ} \mathrm{c} .^{(1,29,30)}$

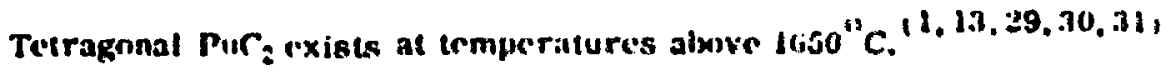
Or comling, the transformation of $\mathrm{PuC}_{2}$ in $\mathrm{P}_{\mathrm{U}_{2}} \mathrm{C}_{3}$ is su rapid that difficulty is encountered in quenching in the PuC phase. The peritertic meleing juint of PuC 3 "s

$$
-2-
$$


Talsle 1

The Carbon Content of $\mathrm{PuC}_{1-\mathrm{x}}$

\begin{tabular}{|c|c|c|c|}
\hline Temperature & Reference & $\begin{array}{c}\mathrm{Pu}_{3} \mathrm{C}_{2}-\mathrm{PuC} \text { Boundary } \\
\text { a o Carbon }\end{array}$ & $\begin{array}{l}\text { PuC }-\mathrm{Pu}_{2} \mathrm{C}_{3} \text { liounciary } \\
\text { a/o Carbon }\end{array}$ \\
\hline$<: 3110^{\circ} \mathrm{C}$ & 2 & $45, t-1.5 .4$ & $\cdots$ \\
\hline IIII & 20 & $45.4-46.8$ & $\cdots$ \\
\hline $5: 35$ & 18 & $4: 3-4 i$ & $4 \times$ \\
\hline 575 & 2 & $+1.1-43.2$ & $\cdots$ \\
\hline $570-. j ! 15$ & 6 & 43.5 & is \\
\hline 6110 & 21 & 40 & 49 \\
\hline 610 & 18 & $+2-43$ & is \\
\hline 6.34 & 21 & 38 & $4 y$ \\
\hline 1000 & 20 & 45.4 & $\cdots$ \\
\hline
\end{tabular}


liquin - citrlon is $2210 \pm 10^{n}$. $(1,29)$ Tetragonal $P u C_{2}$ is isostruchural witi tetragenal $\alpha-\mathrm{IC}_{2}$ : no evidence for the existance of a $\mathrm{PuC}_{2}$ analog of cuijic $3-\mathrm{IC}_{2}$ has bren repertedi.*

Physical Propertics:

The physical properties which have been experimentally determined for the plutonium corbinles are listed in Table 11 . It is important to note that the physical propertics listed in Table II hase not been deternined as a function of the earion concentration except the measurements of hardness.

A comparison of the free encrgies of formation expressed in Table II with the free encrgies of formation of the uranium carbides ${ }^{(45)}$ indicates that plutonium c:arbides gencrally are less stable than the corresponding uranium carbides, but far more stable than originally reported. (46)

It is difficult at this time to calculate the thermodynamic values at $29{ }^{\prime \prime} K$ with any certainty. The heat content of $P u C_{1-x}$ has been measured in a drnp calorimeter. (44) These results were combined with reported equilibrium data and tabulated functions for plutonium and carbon to give the standard thermodynamic quantities at $298.15^{\circ} \mathrm{K}$ shown in Table III. Since the heat capacity of $\mathrm{Pu}_{2} \mathrm{C}_{3}$ has not been determined, only the heat of reaction is shown for the sesquicarbicle. The results calculated for $\mathrm{PuC}_{1-\mathrm{x}}$ from vaporization data ${ }^{(39,40)}$ do not agree internally, nor do they agree with thuse derived from the electronntive force measurements. ${ }^{(41)}$ The absolute entropy of $\mathrm{PuC}_{1-\mathrm{x}}$ from electromotive force results is in fairly goorl agrecment with that of UC (14.2 e. u.). Similarly the heat of formation of $\mathrm{I}^{\prime} \mathrm{H}_{2} \mathrm{C}_{3}$ obtained by electromotive force ineasurements is approximitely the same as that of $\mathrm{l}_{2} \mathrm{C}_{3}$. It is sonewhat surprising that the heat eapacity of $\mathrm{PuC}_{1-x}$ is less than that of $\mathrm{I} . \mathrm{C}$, in vicw of the fact that $\mathrm{U}$ and $\mathrm{LO}_{2}$ have lower heat capacities than $\mathrm{Pu}$ and $\mathrm{PuO}_{2} \cdot(+7,+8,49,50)$ Obviously the thermochemical data on plutonium

- llecently the llarwcll workers reported evidence for the existance of cubir $\mathrm{PuC}_{2}$ above $1800^{\circ} \mathrm{C}$. 
Table II

Mepurted Phyoical Properties of Plutonium Cartishes

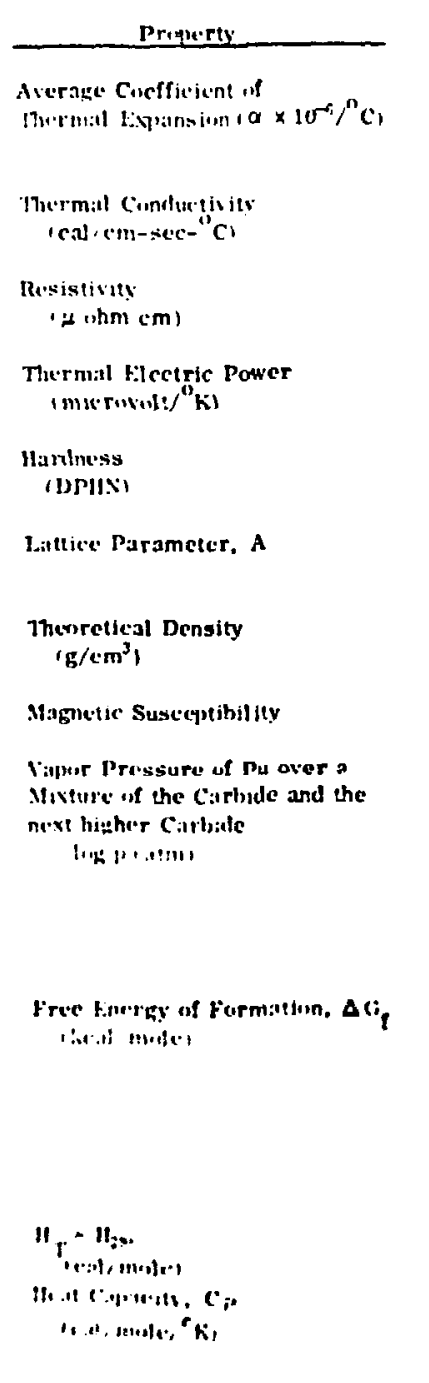

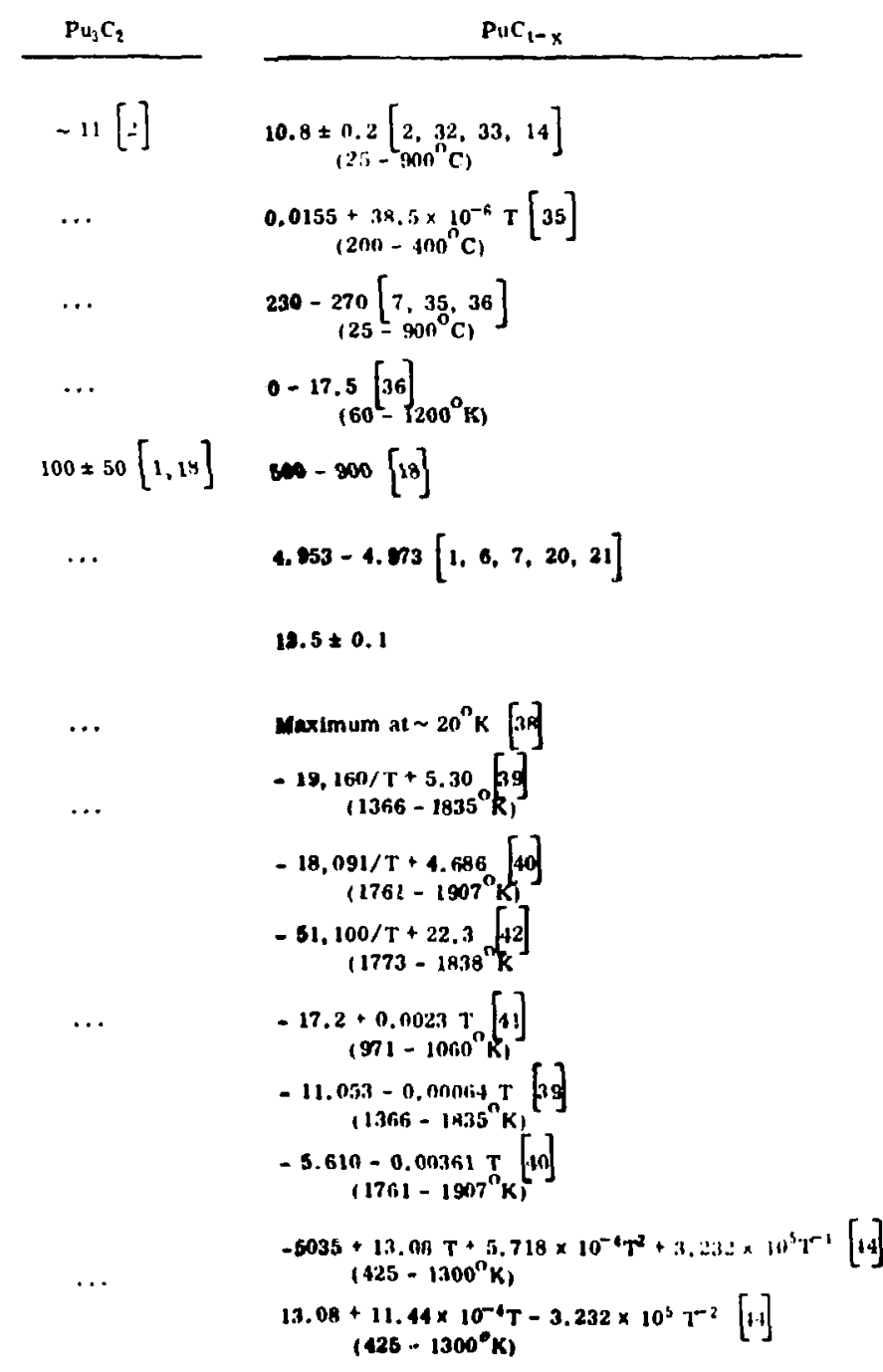

$P_{1} C_{2}$

$$
\begin{array}{r}
1.5 .5 \times 11.7[32,33] \\
\left.120-800^{41} \mathrm{C}\right)
\end{array} \quad \ldots
$$

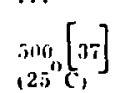$$
\left.\begin{array}{l}
0-23-20[37 \\
(0-100-200
\end{array}\right]
$$$$
\sim 1100[18]
$$$$
\left.8.121-8.134[1,7,10.20] \quad \begin{array}{l}
a=3.63[31] \\
c=6.09
\end{array}\right]
$$

$12.7 \pm 0.1$

20.9

$\therefore$

$-20,330 / \mathrm{T}+4.39[39]$
$\left(1541-1980^{\circ} \mathrm{K}\right)$$$
\text { .. }
$$

$-17,920 ; T+2.779[43]$ $(2000-2400 \%)$

$-16,732 / \mathrm{T}+3.618 \mathrm{fdC}$ $\left(2017-2472^{\circ} \mathrm{K}\right)$
$-236.2+10.0072 \mathrm{~T}[\mathrm{HI}]$
(67.) - 1091 k)
$-13.310-0.00239$ T [33] $(1 ; 311-10404 \mathrm{k}$
$-16.0[10]$

-is. :3111 - 11. 161102 T [15

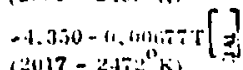

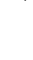$$
\left(426 \cdot 1300^{\circ} \mathrm{K}\right)
$$ 
Table Hl

Standard Thermudynamic Propertics of llutonium Carbides at $29 \times .15^{\circ} \mathrm{K}$

\begin{tabular}{|c|c|c|c|c|}
\hline Compound & $\begin{array}{c}-\Delta H_{23 \%:}^{\prime \prime} \\
\text { kcall/mole }\end{array}$ & $\begin{array}{l}\Delta s_{29 R}^{\prime \prime}, \\
\text { c. u. }\end{array}$ & $\begin{array}{l}5.49 \\
.5 .4 . \\
\end{array}$ & Ilcference \\
\hline $\mathrm{PuC}_{1-\mathrm{x}}$ & 191.04 & 3.49 & 18.2 & 39 \\
\hline$"$ & $4.1 i$ & 6.46 & 21.2 & $i(1$ \\
\hline$"$ & 16.2 & 0.55 & 15.3 & 41 \\
\hline $\mathbf{P u}_{2} \mathrm{C}_{\text {? }}$ & 21.2 & & & 39 \\
\hline$"$ & 11.4 & & & 40 \\
\hline$" 1$ & 48.1 & & & 41 \\
\hline
\end{tabular}


carbides must be considered as provisional.

Plutonium momocarbide containing $\sim 10^{\prime}, \quad \mathrm{Pu}_{2} \mathrm{C}_{3}$ impurity has been foumi to react with the nickel in stainless steel when heated in contaci at $1050^{\circ} \mathrm{C}$ for 120 hours. ${ }^{(14)}$ It is unlikely that $\mathrm{PuC}_{1-x}$ that contains significant amounts of frce plutonium metal will be compatible with $\mathrm{Ni}$, Co, or Fe base alloys, as low melting binary cutectics are formed. Less reaction has been found between $\mathrm{Pu}_{2} \mathrm{C}_{3}$ and the refractory metals. The amount of reaction zone decreased in the order niobium > molybxienum > tantalum > tungsten.

\section{Irradiation:}

Plutoniun carbides by themselve's are not normally considered as portential power reactor fucls, and very little ir radiation experience has been obtained. $A$ few irradiations of arc-cast PuC $_{1-x}$ powder and vibratery compacted PuC $C_{x}$ have been reperted. ${ }^{(5) /}$ Burn-ups of $\sim 3 \times 10^{19}$ fissions/ce of the are-cast specimens and up to $12.9 \times 10^{20}$ of the vibratury compacted $\mathrm{PuC}_{1-\mathrm{x}}$ have been oblained. Most specimens cracked during irradiations and one specimen of vibratory compacted $\mathrm{PuC}_{\mathrm{X}}$ of $6.22 \mathrm{w} / \mathrm{o}$ carbon reacted disastrously with the 304 stainless steel cladding after $12.9 \times 10^{20}$ fissions/cc. The fission gas release, where measurable, was low, $\sim 0.24 \pi$. 


\section{RF.FELENCES}

1. R.X.R. Mulford, F.H. Ellinger, G.S. Hendrix, and F., D. Albrecht, "The Plutonium-Carbon System," Plutoniun 19rio, Ki. by E. Grison, W. B. H. Lord and R.D. Fowler, Cleaver-llume Press Lid., London, (1961)

2. A. E. Ogard, C. C. Land, and J.A. Leary, "The Thermal Expansion of PuC and PuC-LC Solid Solution, " $. .1-2768$ (1962)

3. T.D. Chikalla, "Lattice Constanls and Phase Relations of Arc-Melted Plutonium-Carbon Alloys," HW-74024 (1962)

4. O. L. Kruger, "Preparation and Some Properties of Arc-Cast Plutonium Monocarbide," J. Nucl. Mater., I, 142 (1962)

5. M. Palfreyman and L. E. Russell, in Powder Metallurgy in the Nuclear Age, Plansee Procecdings 1961, Ed. hy F. Benesovsky, Metallwork Plansee AG., Reutte/ Tyrol, 417 (1962)

6. S. Rosen, M.V. Nevitt and A.W. Mitchell, "Metallographic and X-ray Observations of Pil-C Alloys," J. Nucl. Mater., 10, 90 (1963)

7. R. Pascard, "Études preliminaires fur le systène plutonium-carbone et les solutions solides carbure d' uranium-carbure de plutonium," in Powder Metallurgy in the Nuclear Age, Plansec Proceedings 1961, Ed. by F. Benesovsky, Metallwork Plansec AG., Reutte/Tyrol, 387 (1962)

8. A. E. Ogard, W. C. Pritchard, R. M. Douglass, and J.A. Leary, "The Powder Metallurgy of Plutonium Fucl Materials, " Bid, 364.

9. A. E. Ogard, W.C. Pritchard, R. M. Douglass, anl J. A. Leary, "The Preparation of Liranium Monocarbide-Plutonium Monocarbicic Solid Sritutions, Plutoniun Sesquicarbide and Plutunium Monocarbide," J. Inorg. Nucl. Chem. , 24, 29 (1962)

10. R. E. Skavdahl, "The Reactions Botwcon $\mathrm{PuO}_{2}$ and Carbon," Trans. $\mathrm{Am}$. Nucl. Snc. , 6. 393 (1963) 
11. R. Ainsley, 13. R. Harder, M. Hulke, R. C. Sisten, D. H. White, and D. C. Worl, "C"aribles as Reactor leuels: Preparation from Oxides and

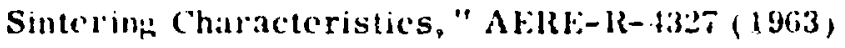

12. I1. Batirot, I. Lafomtaine, and $A$. Pizzolu, "Description of the Belgonucleaire - C. F. N. Work on Plutonium Bearing Carbides," in Carbules in Vuclear Fnergy, Vol. 2, Eal. by L.. E. Russell et al. . Mavomillan and Co. Letd., London, 469 (1964)

13. J. L. Drummond, B.J. McDonald, H.M. (Xekenden, and G.A. Welch, "The Preparation and Properties of Sunce Plutoniun Compounds.

Part VIl. Plutonium Carbides," J. Chem. Soc., IV, 4785(1957)

14. F.C. Re'sheunitov, el al., "Preparation and Studies of Some Properties of Plutunium Monocarbides," in Plutomium 195.5, Ed. by A. E. Kay and M. 11. Waldrou, Chapman and Hall, London, (1967)

15. F. Brown, F.S. Dennerd, P. Ellis, P. T. Good, and R. Lapage, "The Preparation of $\mathrm{Pu}-, \mathrm{U}-$, and Mixed ( $\mathrm{Pu}, \mathrm{U}$ ) - Carbides by the MetalIlydrocarlon Gas Reaction," in Carbides in Nuclear Energ;, Vol. 2, Ed. I.Y I. F. Russell et al. Macmillan and Co. Ltd., London, 692 (1964)

16. 13. P. Ell wotl and A.C. Larson, "Delta-Prime Plutonium," The Metal Plutonium, Ed. by A.S. Cofïinberry and W. N. Miner, University of Chicago Press, Chicago, 265 (1961)

17. D. F. Bowersox, J.A. Leary, "The Solubility of Carbon, Tantalum, Tungsten, and Rhenium in Liquid Plutonium," J. Nucl. Mater., 21, 219 (1967)

18. K. A. Johnson, "Metallngraphic Preparation and Observations of Some Plutonium-Carbon Alloys." L.A-3191-MS (1965)

19. W. H. Zachariasen, "Ihe Crystal Structure of Plutonium Nitride and Plutunium Carbide," The Pransuranium lahements National Suchar Einergr Serices, IV-1113, Ed. ly G. T. Sealierg, J. J. Katz and W. M. Manning, McGraw-1lill Book Co., Ine., New York, 144N (1949)

20. O.L. Kruger, "Phase Sf(klie's on Are-Melted Plutonium-Carlxin Alboys Near the Monoc:arbide Composition," J. Am. Ceram. Soc., 46, XU(391i3)

21. J. B. Burnhạm, R. F. Skavdahl, and T.D. Chikalla, "Plutnnium Bearingr 
Refractory Carbides," Carbides in Nuclear Energe, Vol. 1. Fd. by L, E. Russell et al. Maemillan and Co. Lid., Lundon, $51,194 j+1$

22. F. Anselin, G. Dean, R. Lorenzelli, and R. Pascard, "On the Systern ¿ L Pu) (CNO, as Applied to Sintered Carbides. Carlxonitrides and Oxycarbides," Ibid, 113.

23. R. N. R. Mulford, R. Il. Fill inger, and K. A. Johnson, "'The PlutoniumCarbon-Oxygen System," J. Nucl. Mater., 17, 32q (29tij)

24. K, Mondelssohn, E. King, J. A. Lee, M. H. Rand, C. S. Griffin, R.S. Street, "Self-Irradiation Dimage in Tranuranic Elentents and Cumpounds, " Plutonium 1965, Ed. by A. E. Kay and M. B. Waldron, Chapman and Hall, London, (1967)

25. C.W. Bjorklund, R. M. Duuglass, and R. L. Nance, "X-llay Powder Diffraction," LA-3820-MS, 17 (1967;

26. O.L. Kruger, "Constitution and Properties of Plutonium Monocarbide," Compounds of Intercst in Nuclear Reactor Technology, Ed. by I. T. Waber and P. Chiotti, American Institute of Mining, Metallurgical and Petroleum Eugineers, Inc., 387 (1964)

27. J.L. Gricen, G. P. Arnold, J.A. Leary, N.G. Nereson, "A Luw Temperature Magnetic Transition in Plutonium Monocarbide," J. Nucl. Mater. ,23, 231 (19ti7)

28. W. H. Zachariasen, "Crystal Chemical Studies of the sf-Series of kilements. XV. The Crystal Structure of Plutonium Sesquicarbide," Acta Cryst. 5. $17(1952)$

29. J. (;. Reavis, M.W. Shupe, C.W. Bjorklund, J.A. Leary, "Phase lelations in the High-Carbon Portion of the L-Pu-C Systen, "Trans. Am. Sucl. Soc., $111(191 i \overline{7})$

30. J.T. Dalton, "Lquilibria in the System Uranium-Plutomium-Cartum," Carbides in Nuclear Energe, Vul. 1, Hel. by L. E. Russell et al., Matcmillan and Co. Ltd., Lomdon, 77 (1964)

31. D. M. Chack rahurtty and N.C. Jayadevan, "Crystal Chemistry of Jijigher Carbides of Flutonium," Acta Cryat., 18, 811 (1965) 
32. P.G. Pallmer, "Thermal Expansion of Plutonium Carbides," IrW$732.5(1962)$

33. M.H. Rand and R.S. Street, "Anomalous Thermai Expansions in the Plutonium Monocarbide Kegion," Carbides in Nuclear Energy, Yol. 1, Ed. by L. E. Russell et al., Macmillan and Co. Ltd., London, 108 (1964)

34. M. H. Hand and H.S. Street, "High Temperature X-ray Diffraction Studies, Part 3. Plutonium Nitride and Plutonium Sesquicarbicle," A ERE-M1-973 (1912)

35. J.A. Leary, R. L. Thomas, A. E. Ogard, and G. C. Wonn, "Thermal Conductivity and Electrical Resistivity of LC, (UPu) C, and PuC," Carbides in Nuclear Energy, Vol. 1, Ed. by L. E. Russell et al. Macnill an and Co. Ltd., London, 365 (1964)

36. P. Costa and F. Lallament, "Resistivite et Pouvoir Thermnelectriques ses Carbures de Thoriun, d' Uranium et de Plutonium," Phys. Letters, , 21 (1963)

37. P. Costa, R. Lallement, F. Ansel in, and D. Rossignol, "Magnetic Transitions in Uranium and Plutonium Monitrides, Monocarbides, and Sesquicarbides, " Compounds of Interest in Nuclear Reactor Technology, Ed. by J. T. Waber and P. Chiotti, American Institute of Mining, Metallurgical and Petroleurn Engineers, Inc., 83 (1964)

38. D. J. Lam, M.V. Nevitt, J.W. Ross, L.W. Mitchell, "The Magnetic Susceptibility of the Monocarbides of Uranium and Plutonium, " $\mathrm{Plu}-$ tonium 1965, Ed. by A.F. Kay and M.B.Waldron, Chapman and Hall, London, 274 (1967)

39. W.M. Olson and R.N.R. Mulford, "Thernodynamics of the Plutonium Carbides," Thermodymanics of Nuclear Materials, with Fmphasis on Solution Systems, LAFA, Vienna (1967)

40. P.S. Ilarris, 13.A. Phill ips, M. H. Rand and M. Telonbaum, "The Volatility of Plutonium Carbides, Part 1. AERE-R-5353, (1967)

41. G. M. Camphell, L.J. Mullins, J. A. Leary, "Thermodynamic Properties of Plutmium Compounds by Electromotive Force Techniques," Thernodynamics of Nuclear Materials, with Emphasis on Silution Systems, IAEA, Vienna (1967) 
42. M. Palfreyman and P. E. Potter, "The Volatility of Plutonium Carbide," Carbides in Nuclear Energi, Vol, 1, Ed. hy L. E. Russell, et al., Macmillan and Co. Ltd., London, 336, (1964)

43. R. N. R. Mulford, J. O. Ford, J.G. Iioffman, "The Vulatility of Plutonium Carbide," Thermodynamics of Nuclear Materials, LAEA, Vienna, 517, (1962)

44. O. L. Kruger and H. Savage, "Heat Capacity of Piutonium Monorarbide from 400 to $1300^{\circ} \mathrm{K}, " \mathrm{~J}$. Chem. Phys., 40, 3324(1964)

45. E. K. Storms, The Refractory Carbides, Academic Press, New York and Londun, (1967)

46. E.J. Huber, Jr. ant C. E. Holley, Jr., "The Thermodynamic Properties of the Actinide Carbides Including New Mensurements of the Heats of Formation of Some Thorium, Uranium, and Plutonium Carbides," Thermodynamics of Nuclear Materials, IAEA, Vienna, 581, (1962)

47. K. K. Kelley, et al. "High-Temperature Heat Contents of Uranjum, Uranium Dioxide and Uranium Trioxide," J. Am. Chem. Soc., 69, 2105 (1947)

48. A. E. Kay and R.G. Loasby, "The Specific Heat of Plutonium at High Temperatures, " Phil. Mag. , 9, 37 (1964)

49. "Heat Capacity of $\mathrm{PuO}_{3}, " \mathrm{MLN}-1402,45$, (1967)

50. A. E. Ogard, J. A. Leary, "High Temperature Heat Content and Heat Capacity of Uranium Dioxlde and Uranium Dioxide-Plutonium Dioxide Sol id Solutions, "Thermodynamics of Nuclear Materials, with Emphasis on Solution Systems, LAEA, Vienna (1967)

51. L. A. Neimark, I H. Kittel, C. C. Crothers, "Irradiation of Pu-C and (UPu)-C," Carbides in Nuclear Energy, Vol. 2, Ed. by L. E. Russcll et al., Macmillan and Co. Ltd., London, 864 (1964) 


\begin{abstract}
APPENDIX C
Differential Thermal Analysis Apparatus for

Observation of Refractory Plutonium Compounds *
\end{abstract}

by

J.G. Reavis, J.F. Buchen, and J.A. Leary

Los Alamos Scientific Laboratory

University of Cal ifornia

Los Alamo8, New Mexico 87544

\begin{abstract}
An apparatus has been constructed and used for measurement of melting points and temperatures of crystallographic transitions of refractory compounds of $\mathrm{Pu}$ and other intense alphe emitters potentially useful as reactor fuels. Tine thermal analysis apparatus responds to light energy radiated by the sample and furnace and temperatures are measured by optical pyrometry. The specialized nature of the equipment made necessary an intensive calibration study over the temperature range $1000-2440^{\circ} \mathrm{C}$.
\end{abstract}

* Work performed under the auspices of the Atomic Energy Commission 


\section{Introduction}

Mcasurcment of the properties of reiractory materiais potentiaiiy listeid as reactor fucls presents difficulties not only of containnent to avoid unwanted clemicad reactions at high temperatures, but also containment of the inicnsc alpha activity for protection of laboratory personnel. The differential inermal analysis apparatus described by Rupert ${ }^{(1)}$ is an excelient apparaius for determination of transition temperatures in the range $10 \mathrm{v0}-3000^{\circ} \mathrm{C}$, but a numiver of modifications were necessary in application of the apparatus $u$ studies of intense alpha-emitting refractories such as $(\mathrm{U}, \mathrm{Pu}) \mathrm{C},(\mathrm{U}, \mathrm{Pu}) \mathrm{N}$, and $\mathrm{CO}_{2}-\mathrm{PuO}_{2}$. Additionally; measurements in this high temperature region have been standardized by development of a seriez of reference materials for temperature calibration. It was necessary to develop this series for periodic verification of the accuracy of measurements, since the accuracy could not be rechecked by substitution of a standard lamp in the position of the furnace.

\section{Apparatus}

A schematic view of the apparatus is shown in Fig. 1. Power to heat the furnace is atpplied by a $25 \mathrm{~kW}, 0.45 \mathrm{Mkz}$ generator the outuut of which is coupled to the furnace by an induction coil and current concentrator simiiar $w$ that previously described. (2) The output level of the generator is controiled by an electronic unit which can be adjuated either manually or by use of a nioiorized drive. Controlled heating and cooling rates in the range $10-1000 \mathrm{deg} / \mathrm{mm}$ can be attained; heating rates of greater than $2500 \mathrm{deg} / \mathrm{min}$ can be accomplisheil by manual power adjustment, but the furnace shown in Fig. 1 will not cool more rapidly than about $1000 \mathrm{deg} / \mathrm{min}$.

The furnace assembly is enclosed by a glove box that retiins all rahioactive particles. The furngee consista of a susceptor, an inner crucible, a lid penetrated by a $1 \mathrm{~mm}$ diameter hole, and several radiation relleciors. The use of the reflectors and inner crucible reduces the magnitude of the thernial rradient: 


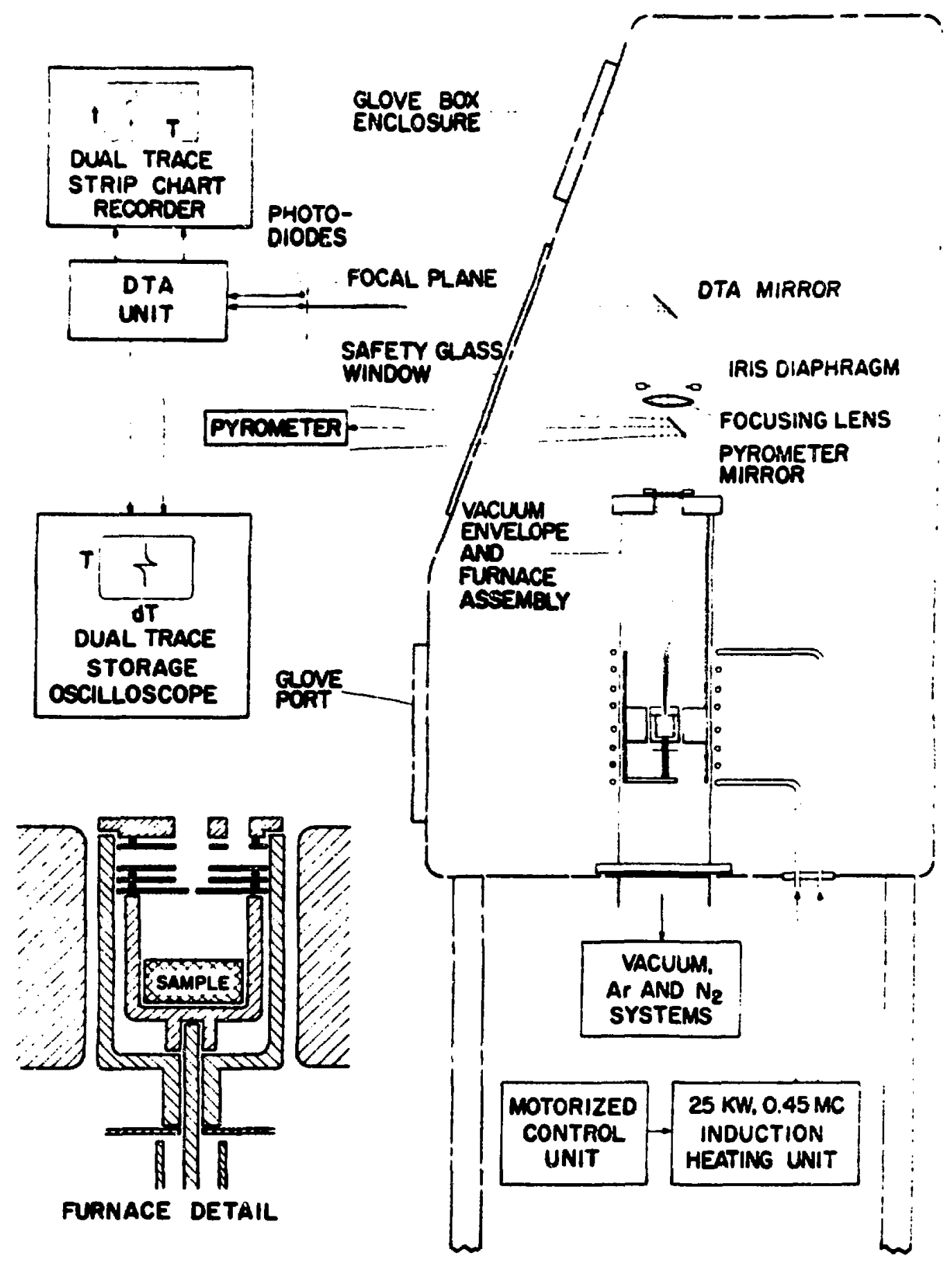

Figure 1. Schematic Drawing of the DTA Apparatus 
which may exist in the sunceptor. The furnace susceptor is : $\mathrm{min}$ hing ard $19 \mathrm{~mm}$ dia. The materiais of construction usually ate Ta, 15 or trajinive, the cholce buing male tn mintmize reaction with the sample to be hrated. Fior observatjons of melting of nuble metals. $\mathrm{ma}_{2}$ erucithes with iho, hids were used as linere for $\mathrm{Ta}$ inner crucibles. Thin axkes of $\mathrm{ThO}_{2}$ are piaceti un top of the highy rebeeting metal samples to avoid direct renection of the sistit hole th the fietd vicwed by the optical prrometer.

Theoptical syolem which transmite rwiant chergy fron the furvace in the optical pyrometer * is atmple. Approximately one third of the divergng beam emerging through the window in the top of the eurrent cencentrator is intercepted by a mirror and reflected to the pyromeler used for actual temperature meaourement. The remaning two thirde of the beam pasacs birough a convex lens and an Irie diaphram and ts refected by a mirror wo produee a magnifive image of the top of the furnace in a vertical plane outside the slove box. One photoconducting diodest is positloned in this plane so that its active area is covered by the image of the hole in the cruelble lid. $A$ second diode is coverct by the imnge of a small ares of the aurfece of a rediation shictd as secn througit the second hole in the suaceptor lid.

SIgnale from the diodes are amplified by a syotem very similar lit tliat previoualy deecribed. ${ }^{(1)}$ Electrical outpute proporitional to (i) cempcrature $1 \%$, of the sample, (2) difference between sample temperawre and radiation shicici temperature (AT), and (3) derivative of eample temperature with reape'(t) to tums: (dT/dt) are produced. T and $\Delta T$ oignals are recorded simultanenualy by a iur pen strip chart recorder while a storage oscilloscope is uutel to recori $T$ is is function of dTAlt. For very fast thermal cycles, the oscilloscoju in found inu:ve uschul in the recording of $r$ and $\Delta T$ as 2 function of tine. The recorcier trises indicating temperature is caltbrated by observing temperatures with the pyrumivicer

\footnotetext{
* Micro Optical Pyrometer, The Pyrometer Instrument Cu. Inc. . Bergenficid, N. s. * Diode IN-2175, Texas inntruments, Inc.. Dallas, Texas.
} 
during artual thermal cyctitu of samples.

\section{iii. Culbration}

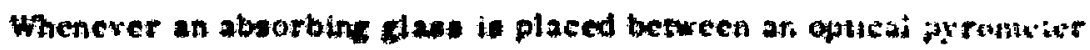
idisapearing filament type) and an incandeecent object the reiatiwastup botucen

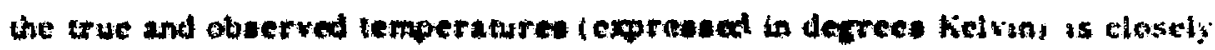
aproximated by

$$
\frac{1}{T}=\frac{1}{T} \cdot A
$$

where $T_{0}$ to the oberved temperature, $T$ is the true temperature, and $\lambda$ is $*$ constant for a given absother. (3) By we of a calibrated optical pyrameter and a tungeten atrip lamp over the range $1000-1800^{\circ} \mathrm{C}$, the value of $A$ wis found to be $19 \times 10^{-4}$ dec ${ }^{-1}$ for a mock-up of windowe and a mirror to be und in the asscmbled 4paratus. The prection of the mesurements used in ealculation of the value of $A$ in equation ( $\lambda$ ) indieated uncertainties in the semperature correction tor absorbance by the optical syatem of $\approx 2^{\circ}$ at $2000^{\circ} \mathrm{C}$ increasing to $\approx 9^{\circ} 213000^{\circ} \mathrm{C}$.

Additional tuncertaintie in the value of $A$ could arise from use of a slifidy different geometry of actud contruction of the apparatus or from chauge of absorbance of the componente 1 including the window of the glove box enciosure) with passage of time. These conaiderations mede it necessury to theck perjotically the accuracy of meanurement of temperatures in the assenabled apparatus. Since placement of a calibrated tungsten atrip lamp in the postlion of the furnnce de imponaible, the alternative procedure of obervations of trankitione of reference materials was adopled for final calibration of the ivparatus. The choce of thia method producea a correction curve which secuunts for optutal ulssurption, pyrometer ecalo errore and eyotematic crrore involved in recording anl interpreting DTh curves. The materiale chosen for reference are listed in Table 1. 
Table I. Reference Materlals Used in Calibration of the DTA Apparatus

\begin{tabular}{|c|c|c|c|c|}
\hline \multirow[b]{2}{*}{ Miterial } & \multirow[b]{2}{*}{ Container } & \multirow[b]{2}{*}{ Transition } & \multicolumn{2}{|c|}{ Transition Temp. " $\mathrm{C}$} \\
\hline & & & $\underline{\text { Lil. }}^{(\mathbf{a})}$ & Observed \\
\hline $\mathrm{Cu}$ & C & melting & 1083 & $108:$ \\
\hline Pt-C & C & eutectic & 1734 & 1735 \\
\hline Pi & Tho & melting & 2770 & 1770 \\
\hline $\boldsymbol{R h}$ & Tho & melting & 1960 & 1960 \\
\hline $\mathrm{A}_{2} \mathrm{O}_{3}$ & $\mathbf{w}$ & melting & 2050 & 2047 \\
\hline $\mathrm{MoC}_{0.3}$ & $\mathbf{c}$ & eutectic & 2205 & 2205 \\
\hline Ir & $\mathbf{m a n}_{2}$ & melting & 2440 & 2440 \\
\hline
\end{tabular}

(a) Litorature values selected after study of ref. 4-9.

(b) See cext for discusston of aceuracy. 
IV. Performanre

The apparatus has operated satisfacturily over a perind of nore ibis a years of obscrvation of thermal effects in carbides, nitrides, and oxides of uratisum and plutonium. Repeateci observations of duplicate samples have showzi triat a single isolated measurement of a transition temperature has an uncertainty limit of about $\pm 10^{\circ}$ if proper care is taken to exclude systematic errors such as those arising from reaction between sample and container, decomposition of tise sample or fogging of the current concentrator window by vaperization of the sample or furnace parts. Fogging of the window can be a serious problem during measurements in vacuo but was almost eliminated by filling the apparatus with an inert gas. The reference materials listed in Table I were observed under Ar.

Two or more samples of each reference material were observed. Transition temperatures observed during heating (melting) were found to be more casily reproducible than those observed during cooling because of severe undercocling shown by almost all samples. Reversibility of the transition was snown in each case by slight reduction of furnace power to produce freezing before mel ting was completed.

Observed and literature values of transition temperatures of each reference material were usfd to calculate a value of $A$ (Equation 1) for that observation. These values of $A$ were averaged to produce a new value of $20.5 \times 10^{-6} \mathrm{deg}^{-1}$ to replace the value of $19 \times 10^{-6} \mathrm{deg}^{-1} \mathrm{derived}$ by use of the mock-up and the $W$ strip lamp. The new val ue of $A$ was used to generate a smoothed correction curve for the range $1000-3000^{\circ} \mathrm{C}$. Absorbance corrections from this smoothed curve were added to the uncorrected transition temperatures determined for the reference materials. These values are listed as "Observer" transition temperatures in Table $I$. The number of determinations of the transition temperature of any given reference material was not sufficienuly great 
in : allow mowingful determination of alandard deviationa al each temperalurt.

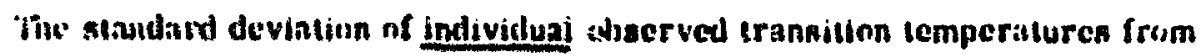

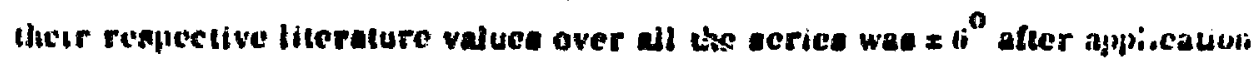
of the amoothed correction curve. The averoucd valuea of transition cemperatures listivl in male I show standerd deviation of $\pm 1,5^{\circ}$ from ibvir reapective literature values.

It apuears that reference materiale are necded to achieve a high deigree of accuracy in measurements of tranation temperatures. The vilues lusted in. Table 1 are about $12^{\circ}$ higher at $24+0^{\circ}$ and $3^{\circ}$ higher at $1680^{\circ}$ than thuse based on the A-value determince by une of the window mock-up and the $W$ strip lamp. Although this difference has about the same value as the uncertainty of a singje determination, use of the new correction curve gived a aignificant improvement in the accuracy of tranaition temperatures based on multiple abservations.

The validity of the correction curve has been rechecked periodically over a poriod of several months of use by obeervation of reference materials selected from those listed in Table 1. No aignificant change has been detected even though many macro samples of intense alpha emitters have been observed during this period. Greater changes may be expected, however, in systems in which windows are subjected to high levels of more penetrating radiations or to extremes of temperature.

\section{ACKNOWLEDGMENT}

The authors are indebted to G. N. Rupert for helpful advice and to R.G. Sturgess for moditication and construction of the amplifier aystem.

\section{REFERENCES}

1. G. N. Rupert, Rev. Sci. Instr., 36, $1629(1965)$.

2. G. N. Rupert, Rev. Sci. Instr., 34, 1183 (1963). 
3. H.J. Kostkow6ki ald R.D. Lee. "Thenry and Methode of Optical lyeronctry," NiBS Monograph 41 (1962).

4. JANAF Thermochemical Tables, ed. by D. ll. Stull, The Dow Cheniacai Co., Midland, Mich. (1964).

5. National Bureau of Standarda Circular 500. "Selected Values of Chelliacie Thermud!namic Properties," cl. by F.D. Rossini, D.D. Warman ul. ul. 119521 .

6. M. Hansen, "Conetitution of Binery Alloys," MeGraw-Hill Co., Xew York, N. Y. (1958).

7. H.F. Stimbon, "International Practical Temperature Scale of 1946 (Text Revision of 1960)," NBS Monograph 37 (1961)

8. S.J. Schneider and C.L. McDaniel, Rev. Hautes Temper, et Refract., 3. 351 (1866).

9. M. R. Nadler and C. P. Kempter, J. Phys. Chem., 64, 1468 (1960). 


\title{
CERAMIC PLLTONIUN FUF, MA TEMIALS IRESEATCI AT I.OS ALAMOS SCIENTIPIC LABORA IOLIY
}

\author{
by \\ J. A. Leary and R. A. Kent \\ Invited paper for presentation on Scptember 17, 1969 at the Japan Atomic Encrgy \\ Research Institute, Tokai-mura, Japan \\ Contribution from Los Alamos Scientific Laboratory \\ University of California, Lus Alamos, New Mexico U.S.A.
}

This paper is based on the work sponsored by the United States Atomic Encrgy Commission 


\title{
CERAMIC PIU'IONIUM FUEL MATERLAIS RESFARCH \\ AT LOS ALAMOS SCIENTIFIC LABORATORY
}

by

\author{
J.A. Leary and R. A. Kent
}

\section{INTRODLCTION}

Plutoniun high temperature researeh at Los Alamos Scientific Laboratory Is sponsored prinarily by the Division of Reactor Devclopment of the USAEC. Other associated programs involve studies on the compatibility of plutonium fuels with potcntial cladding materials, and the irradiation performance of such fuels. All of these programs are directed toward inc utilization of plutonium in fast breecier nuclear reactors.

The high temperature matcrials research program may be divided into three broad categories: (1) synthesis and fabrication, (2) physical properties, and (3) chemical properties. Procedures have been developed for synthesizing and fabricating plutonium monocarbide, plutonium sesquicarbide, plutonium dicarbide, plutonium dioxide, plutonium scsquioxide, and plutonium mononitride. In addition, solid solutions of most of these compounds with the corresponding uranium compounds have been produced. In all cases the objective is to prepare well characterized pure single phase materials. In the sccond category, the thermal conductivity, thermal diffusivity, clectrical resistivity, compressive creep, hot hardincss, and thermal cxpansion of fuel materials are being deterrined. The third category includes characterization by chemical analysis, crystallog:aphic siructure analysis, and measurement of thermochemical properties. This paper is concerned only with this third category, and each phase of research in this category will be discussed briefly. 


\section{STRUC'TURE ANALY'SIS}

X-ray diffraction: The structures of plutonium materials at room temperature are determined by conventional $\mathrm{X}$-ray powder diffraction techniques. In addition, an $\mathrm{X}$-ray powder diffractomc!er furnace has been designed and fabricated for lise in the investigation of the high temperature crystallographic properties of plutonium and uranium-plutonium carbides. The furnace design is based on a preciscly located, resistance heated graphite strip which also serves as the sample support. The unit can be used for the collection of quantitative diffraction data at temperatures up to approximately $2600^{\circ} \mathrm{C}$. The primary uses of the apparatus are phase identification, basic structure studies, and the detcrmination of lattice parameters as a function of temperatirie. The capability of obtaining diffraction data at the temperature of interest allows the dircct observation of phase transitions with positive identification of phases present, thus avoiding the uncertainties involved in indirect methods such as quenching studies. $\mathrm{X}$-ray diffraction studies of $\mathrm{PuC}_{2}$ have shown the following:

1. When samples of $\mathrm{PuC}_{2+\mathrm{x}}$ are quenched from high temperature, oniy tetragonal $\mathrm{PuC}_{2}$ is obtained. However, the only stable dicarbide is the cubic modification. No region of stability has been found for the tetragonal modification. It appears that the tetragonal dicarbide is a metastable species.

2. $\mathrm{Pu}_{2} \mathrm{C}_{3}$ has a relatively large cocfficient of thermal expansion; the mean linear cocfficicnt of expansion between $20^{\circ}$ and $1600^{\circ} \mathrm{C}$ is $15.6 \times 10^{-6}$ per ${ }^{\circ} \mathrm{C}$.

3. The thermal expansion of cubic $\mathrm{PuC}_{2}$ is large. The average expansion coefficient over the temperature range $1750^{\circ}$ ic $2000^{\circ} \mathrm{C}$ is $21 \times 1 \sigma^{6}$ per ${ }^{\circ} \mathrm{C}$.

4. The mechanism and kinetics of the transition of plutonium 
sesquicarbide to dicarbide appear to be rather complex.

An additional high temperalure furnace is being designed for studics on oxide systems.

Neutron diffraction: A ncutron diffraction study of plutnnium monocarbicle at low tenperature using plutonium-2 40 has been completed. Neutron diffraction patterns for this target were taken at various temperatures between room temperature and $20^{\circ} \mathrm{K}$. At approximately $100^{\circ} \mathrm{K}$ an antiferromagnetic transition was indicated by the appcarance of four small but woll defined magnetic reflections. Similar experiments with ${ }^{2}: \mathrm{Pu}_{2} \mathrm{C}_{3}$ targets did not reveal any magnctic transitions.

The carbon aloms in the $\mathrm{Pu}_{2} \mathrm{C}_{3}$ structure occur as dicarbide groups. This bond length was foumd to be $1.39 \mathrm{~A}$ in $\mathrm{Pu}_{2} \mathrm{C}_{3}$ and $1.42 \mathrm{~A}$ in $\mathrm{U}_{2} \mathrm{C}_{3}$.

High temperature neutron diffraction equipment capable of measurements up to $2000^{\circ} \mathrm{C}$ is now in the design stage.

Differential therunal analysis (DTA): The DTA apparatus for plutonium materials shown in Figure 1 has bcen described in detail. (2) This apparatus provides thermal information in various optional forms such as the temperature of sample as a function of time, the difference in temperature of unknown sample and standard sample as a function of time, the time derivative of temperature as a function of temperature or time, etc. Transitions in samples weighing a few grams can bc determined with this instrument, even when the enthalpy change is small. In addition to measuring the temperature of transition, the heat of transition can be determined by the use of s:utable standards.

Normally the results of thermal analysis are supplemental by metallography, electron microprobe examination, and $X$-ray and neutron diffraction studies. In addition, high temperature dilatometry is used to provide direct suppor $\downarrow$ of the transition temperatures observed by thermal analysis.

The DTA apparatus has been used to determine the melting point $\left(2780^{\circ}\right.$ solidus, $2820^{\circ} \mathrm{C}$ liquidus) of $\mathrm{U}_{0.80} \mathrm{Pu}_{0 \cdot 20} \mathrm{O}_{1} \cdot 97$ in sealed $\mathrm{W}$ containers, as 
well as a heat of fusion of $19.4 \mathrm{kcal} / \mathrm{mole}$. The melting point of $\mathrm{PuO}_{2}$ was found to be $2445^{\circ} \mathrm{C}$, while that of $\mathrm{UO}_{2}$ was $2850^{\circ} \mathrm{C}$. Similarly the melting points of nitrides have been measured in open crucibles under various atmospheric conditions. Plutonium mononitride melts at $2305^{\circ} \mathrm{C}$ at a nitrogen pressure of $8 \mathrm{~mm}$ of $\mathrm{Hg}$, and at $2540^{\circ} \mathrm{C}$ under $380 \mathrm{~mm}$ of $\mathrm{Hg}$. At an argon pressure of 400 $\mathrm{mm} \mathrm{Hg}$ (no nitrogen) the melting point of $\mathrm{U}_{0.80} \mathrm{Pu}_{0.20} \mathrm{~N}$ is $2500^{\circ} \mathrm{C}$.

The carbides have been studied in considerable detail. Solidus and liquidus temperatures of various monocarbide compositiuns are plotted in Figure 2. Solidus and liquidus values of the particularly important composition

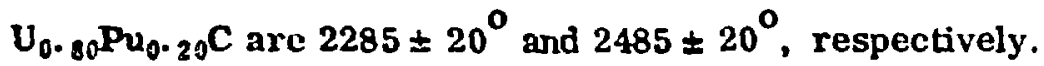

DTA has Ilso been used to outline the major phase fielòs in $(\mathrm{U}, \mathrm{Pu}) \mathrm{C}_{2}$ containing excess $\mathrm{C}$. Thermal arrest temperatures are plotted on Figure 3. Samples have been $q$ uenched from all fields for $\mathrm{X}$-ray powder diffrattion analysis. Even though samples quenched from the $\mathrm{MC}_{2}+\mathrm{C}$ region contain tetragonal $\mathrm{MC}_{2}$, high temperature $\mathrm{X}$-ray diffraction experiments have shown that the stable high temperature form of $\mathrm{MC}_{2}$ is cubic. In the presence of excess carbon, tetragonal $\mathrm{UC}_{2}$ is the stable form from $1515^{\circ}$ to $1765^{\circ}$. Although bec $\mathrm{U}_{2} \mathrm{C}_{3}$ is the stable lattice below $1515^{\circ} \mathrm{C}$, samples of tetragonal $\mathrm{UC}_{2}$ can be held at $1450^{\circ} \mathrm{C}$ for days wt thout transition to $U_{2} C_{3}$. However, when $(U, P u) C_{2}$ compositions are held below the transition temperature, the $(\mathrm{U}, \mathrm{Pu})_{2} \mathrm{C}_{3}$ structure forms rapidly. Over the range 0 to 20 percent $\mathrm{PuC}_{2}$ in $(\mathrm{U}, \mathrm{Pu}) \mathrm{C}_{2}$, tetragonal dicarbide appears to be stable. However, the limita of this region are not yet well defined.

\section{THERMOCHEMICAL PROPERTIES}

Vapor pressure methads: Although the use of the Knudsen technique to measure vapor pressures and heats of sublimation and/or vaporization is well established, vaporization processes at high temperatures are often complex and a detailed knowledge of the identity and relative concentrations of the vapor species in 
equilibrium with the condensed plutonium phases is required if the vaporization process is to be characterized.

In order to determine both the vapor species present over condensed plutonium materials at high temperatures and the partial pressures of these vapor species, the high temperature mass spectrometer assembly shown in Figure 4 has been constructed. The unit consists of two basic components, an oven assembly incorporating an electron bombardment-heated Knudsen cell, and a quadrupole mass spectrometer. These component parts are contained in a differentially pumped Type 304 stainless steel vacuum envelope. Vacuum of the order of $10^{-8}$ torr is achieved with the Knudsen cell at $1600^{\circ}$ by meass of two ion pumps, one rated at $4002 / \mathrm{sec}^{2}$ connected to the quadrupole region, the other, rated at $100 \mathrm{l} / \mathrm{sec}$, connected to the oven region.

The molecular beam which effuses from the Knudsen cell passes through a collimating slit in a movable shutter plate and into the quadrupole region. The movable shutter plate allows one to close the slit to the molecular bcam so as to distinguish sample vapors from background species.

The high voltage power supply is capable of heating the Knudsen cell to $2100^{\circ}$ by electron bombardment from a tungsten wire filament and in tests the Knudsen cell has been held at $1600 \pm 5^{\circ}$ for as long as 24 hours.

The temperature of the Knudsen cell is measured by sighting with a micro optical pyrometer through calibrated winclows into a black body hole in the base of the cell.

This apparatue has been used determine the gaseous species and their vapor pressures above tumber of pirtonkium-containing condensed species.

Plutonium metal was effused from tungsten and thoria Knudsen cells over the range 1126-1658 ${ }^{\circ}$. The results are shown in Figure 5. Liquid plutonium vaporizes to monomeric plutonium gas with a boiling point of $3466^{\circ} \mathrm{K}$. The standard heat and entropy of vaporization are $83.0 \pm 0.5 \mathrm{kcal} / \mathrm{moie}$ and 
$29.1 \pm 0.5 \mathrm{eu}$, respectivaly.

Plutonium trifluoride was he:ited in tantalum Knudsen cells over the range $1243-1475^{\circ} \mathrm{K}$ and the principal vapor species was found to be plutonium trifl uoride gas. (4) The results are shown in Figure 6.

Studics of the equilibria among gaseous species over the mixture liquid plutonium plus solid plutonium trifluoride have established the dissociation encrgy of plutonium monof uoride gas to be $\mathrm{D}_{298}^{\mathrm{c}}=5.53 \pm 0.30 \mathrm{eV}$.

Plutonium mononitride was effused from tungsten Knudsen cells over the range $1658-1976^{\circ} \mathrm{K}$. The results, which are shown in Fig. 7 , indicate that the mononitride vaporizes congruently. (5) Using estimated thermodynamic functions for plutonium mononitride, the heat and entropy of formation were calculated to be $-71.2 \pm 2.5 \mathrm{kcal} / \mathrm{mole}$ and $-19.9 \pm 2.0 \mathrm{eu}$, respectively. Electromotive force techniques: The majority of experiments on electromotive force methods have employed molten $\mathrm{LiCl}-\mathrm{KCl}$ cutectic as the electrolytc. Two princtpal methods have been used: (1) the conventional steady-state measurement, and (2) the galvanostatic or chronopotentiometric method. Procedures and results have been described in detail. $(6,7,8)$ The free energies of formation of plutonium trichloride, plutonium mononitride, plutonium sesquicarbide, plutonium monocarbide, and uranium-plutonium monocarbide have been determined. In general the results are in agreement with those obtalned by vapor pressure methods at this Laboratory.

Most of the recent work has employed the galvanostatic method, as this technique appears to give more reliable results. The procedure involves electrodeposition of plutonium metal from the fused salt electrolyte onto the micrum electrode by a current of constant magnitude, followed by anodic stripping of the metal at constant current. By recording the potential during the procedure and having a theoretical knowledge of the effect of diffusion on the $\mathrm{Pu}^{+3}$ concentration at the electrode surface, the equilibrium potential can be determined. Expcriments 
which inade use of a $\mathrm{Pu} / \mathrm{Pu}^{+3}$ as well us those which made use of a $\mathrm{U} / \mathrm{U}^{+3}$ as reference electrodes indicate the technique is probably accurate to $\pm 1 \mathrm{mV}$ in melts of high purity. The purity of the electrolyte is indicated by the residual current observed in the chronopotentiometric trace.

This galvanostatic technique has becn used to determine the emf of the $\mathrm{Pu} / \mathrm{Pu}^{+3}$ couple vs that of a plutonium mononitride electrode in $\mathrm{LiCl}-\mathrm{KCl}, \mathrm{PuCl}_{3}$ melt, over the temperature range $714^{\circ}$ to $1031^{\circ} \mathrm{K}$.

Since nitrogen is known to react with plutonitun over the range of temperatures of these cxperiments the cell reaction is properly written as

$$
\text { Pu (sat'd with } N \text { ) }+0.5 \mathrm{~N}_{2} \rightarrow \text { PuN }
$$

However the solubility of nitrogen in plutonium is not great enough to cause a significant difference in the emf at these temperatures. For this reason the results are treated as if the cell reaction were

$$
\mathrm{Pu}(\mathrm{s}, \ell)+0.5 \mathrm{~N}_{2}(\mathrm{~g}) \rightarrow \mathrm{PuN}(\mathrm{s})
$$

and the schematic representation of the cell is

$$
\operatorname{Pu}(s, \ell)\left|\mathrm{PuCl}_{3}, \mathrm{LiCl}-\mathrm{KCl}\right| \operatorname{PuN}(\mathrm{s}), \mathrm{N}_{2}(\mathrm{~g})
$$

The results from three cells (after correcting for the thermal emf of Ta vs $W$ and for the difference between the measured pressure of $N_{2}$ and $1 \mathrm{~atm}$ ) are represented by the equation

$$
\begin{aligned}
E=7.90071 & -2.31690 \times 1 \sigma^{2} T+2.517855 \times 1 \sigma^{5} T^{2} \\
& -9.1644 \times 1 \sigma^{3} T^{3}( \pm 0.003 V)
\end{aligned}
$$

with $E$ in volts and $T$ in ${ }^{O_{K}}$.

The results of previous experiments by an indirect method gave 0.8745 $( \pm 0.005) \mathrm{V}$ for the emf at $700^{\circ} \mathrm{K} .{ }^{(6)}$ The recent experiments indicate that the emf at $7.0^{\circ} \mathrm{K}$ is 0.8765 ( $\pm 0.003, \mathrm{~V}$ which is in good agreement. 
Above the melting point of plutonfum the potential is given by the equation

$$
E=1.0672-3.258 \times 1 \sigma^{4} \mathrm{~T}^{\mathrm{N}}( \pm 0.003 \mathrm{~V}) \text {. }
$$

This results in

$$
-\Delta G_{T}^{0}=73.8-0.0225 \mathrm{~T} \mathrm{kcal} / \mathrm{mole}
$$

for the Gibbs free energy of formation of plutonium mononitride in the temperature range $915^{\circ}$ to $1031^{\circ} \mathrm{K}$.

At present the electromotive force technique is being applied to determining the thermochemical propertics of uraniun-plutonium carbides.

Calorimetry: Three calorimeters are being used to evaluate high temperature heat contents and heat capacities of plutonium materials. The high temperature $\left(1300^{\circ}-2900^{\circ} \mathrm{K}\right)$ drop calorimeter has been used to measure these properties with $\mathrm{UO}_{2}, \mathrm{U}_{0.80} \mathrm{Pu}_{0 .}{ }_{20} \mathrm{O}_{2} \cdot{ }_{000}$ and $\mathrm{U}_{0.80} \mathrm{Pu}_{0.20} \mathrm{O}_{1.98}$. Details of procedure and results bave been reported. ${ }^{(9)}$ A schematic drawing of the apparatus is shown in Figure 8. The calorimeter block is a copper cylinder weighing arproximately $28 \mathrm{~kg}$. The central cavity of the block contains a removable insert upon which the electrical calibration resistance heater is wound. A massive off-center copper shutter is incorporated as part of the receiver block. This shutter is interconnected to another antiradiation shutter located at the bottom of the furnace. All surfaces of the calorimeter block are gold plated as is the inside of the container vessel surrounding the block. The exterior of the calorimeter block is wound with one half of a differential copper resistance thermometer. A $1-\mathrm{cm}$ portion is exposed to the falling capsule so that a very accurate zero time is recorded. The other half of the differential resistance thermometer is made of manganin wire wound on a small core and attached to the constant-temperature wate: jacket. The difference in output between these two thermometers is recorded on a Minrieapolis-Honeywell recorder with full range 0 to $20.2 \mathrm{mV}$ in ten steps. The Wheatstone bridge circuit is adjusted so that $1-\mathrm{mV}$ output is 
approximately equal to $1^{\circ} \mathrm{C}$ temperature difference between the two thermometers.

The calibration constant of the calorimeter block is determincd periodically by supplying a known amount of electrical energy to a manganin heater wound on the calorimeter insert. An Electronic Measurements Co., Inc. 0- to 3-A de power supply is used to supply the electrical energy to the heater. The output is put through a dummy heater until stabilization of the power sulply is obtained. It is then switched to the calorimeter heater by a Baird-Atomic Precision Timer Model-930 for a preset length of time. The current and voltage are measured using a Calibration Standard Corp. dc Voltmeter across a $0.01 \mathrm{ohm}$ Biddle-Gray Standard Resistor, and a Hewlett-Packard Digital Voltmeter. A value of $2596 \mathrm{cal} / \mathrm{mV}( \pm 0.5 \%)$ has been obtained for the calibration constant over a perfod of one year.

The furnace consists of a tungsten mesh heating element surrounded by tungsten radiation shiclds. A temperature up to approximately $2700^{\circ} \mathrm{C}$ can be reached with $25 \mathrm{~V}$ and $1100 \mathrm{~A}$.

The sample temperature is measured using a Pyro Micro-Optical Pyrometer. This pyrometer was calibrated against a tungsten-ribbon filament lamp, which in turn was calibrated against a National Bureau of Standards calibrated tungsten-ribbon filament lamp. The uncertainty in temperature measurements using this pyrometer is $\pm 0.5 \%$ at all temperatures.

The tungsten capsule shown in Figure 9 is used to contain the materials. Two methods are used to make the capsules; spark discharge machining of G. E. - 15 crack-free tungsten and also normal slip-casting teclmiques. The capsules are loaded with sintered pellets and then welded shut with $1 / 3$ atmosphere of argon or helium internal pressure.

At the present time measurements have been made only on unirradiated material. The heat contents to $2400^{\circ} \mathrm{K}$ of unirradiated $\mathrm{UO}_{2}, \mathrm{U}_{0.810} \mathrm{Pu}_{0.138} \mathrm{O}_{2} \cdot 00$, and $\mathrm{U}_{0.80} \mathrm{Pu}_{0.198} \mathrm{O}_{1} \cdot 98$ are shown in Figure 10. The heat content of $\mathrm{PuO}_{2}$ is now 
being determined bul as yet there are not cnough results to publish. It is planned that the heat content of $\mathrm{PuO}_{2}$ will be determined up to the melting point. The heat of fusion will also be measured.

In addition, an adiabatic calorimcter has been constructed for direct measurement of heat capacity at temperatures up to $1200^{\circ} \mathrm{C}$, and an intermediate range $\left(300^{\circ}-1500^{\circ} \mathrm{K}\right)$ drop calorimeler is now in use.

\section{ADDITIONAL PLUTONIUM HIGH TEMPERATURE CHEMISTRY RESEARCH}

Several additional plutonium research programs are being conducted for applications other than fast breeder reactor fuels.

Plutonium electrorefining: Ccnventional plutonium metal and its alloys are electrorefined routinely on the multikilogram scale. Metal produced by this process has a purity of 99.99 percent, and is distributed by the U.S. National Bureau of Standards as a plutonium chemical standard. For special applications plutonium-238 and plutonium-242 also are electrorefined. The process, which is well described in the literature, ${ }^{(10)}$ involves the chemistry of molten plutonium metal and molten salt electrolytes. In support of this application, the pseudobinary temperature - composition diagrams of plutonium trichloride with earh of the alkalie chlorides and each of the alkaline earth chiorides (except for irancium, beryllium, and radium chlorides) have been determined and reviewed. $(11,12)$

Phase relationships between plutonium trichloride, plutonium oxy'chloride, and plutonium metal also have been reporled. $(13,14)$ In the area of high temperature metallurgical chemistry, the equilibrium solubilities of all of the refractory metals in liquid plutonium have been determined, $(15,16,17,18)$ and the the rmochemistry of plutonium process reactions at high temperature have been reviewed.

$$
\text { (19) }
$$


Radioisotopic heat sources: Conventional plutonium-238 has a specific power of 0.456 watts per gram of total plutonium isolopes, which is approxinately 200 times that of plutonium-239. Coupled with its long half life, this makes plutonium-23s an ideal heat source material. The development of a heat source for use in ar implantable artificial heart in humans is being conducted at the Laioratory. Interesting high temperature chemistry research has eyolved from plutonium associated with the synthesis and characterization of extremely pure special compounds such as ${ }^{238} \mathrm{PuO}_{2}{ }^{16}$ and ${ }^{23 ?} \mathrm{PuN}^{15}$ for this ayplication. ${ }^{(20,21)}$ The high temperature cincmistry of a solid solution of ${ }^{258} \mathrm{PuO}_{2}{ }^{1 \mathrm{C}}$ and $\mathrm{ThO}_{2}{ }^{1 \mathrm{C}}$ also is being Investigated. This material appears to offer favoruble high temperature preperties that can be utilized in space elcctric power heat source applications.

\section{CONCLLDING REMARKS}

Ten years ago essentially all plutonium chemistry research at the Los Alamos Scientific Laboratory was conducted at temperatures below $100^{\circ} \mathrm{C}$ in aqucous and organic solvent systcms. Today essentially all plutonium chemistiy research is in the high temperature field. This remarkable change was caroce? by the need to utilize plutonium in its numerous forms. Successful utilization requircs a detailed knowledge of high temperature properties, and rescar:h at the Laboratory is currently directed toward expandisy unt kivirleigec in this a:ea.

\section{REFERENCES}

1. "Crystallography and Magnctic Ordering in Plutonium Carbides by Neutron Diffraction," J.L. Green, G.P. Arnold, J.A. Leary, and N.G. Nereson, J. of Nuc. Matter., in press (1968).

2. "Differential Thermai Analysis Apparatus for Observation of Refractory Plutonitun Compounds," J.G. Reavis, J. F. Buchen, and J.A. Leary, Los Alamos Scientific Laboratory Report No. LA-4103 (1969). 
3. "Mass Spectrometric Studies of Plutonium Compounds at High Temperatures. 11l. The Vapor Pressure of Plutonitun," by R. A. Kent, J. of Iligh Temp. Sci. , 1, $169(1969)$.

4. "Mass Spectrometric Studies of Piutonium Compounds al High Temperatures. II. The Enthalpy of Sublimation of Plutonium (III) liluoride and the Dissociation Encryy of Plutonium (1) Fluoride," R. A. Kent, J. of American Chemical Soc., 90, 5657 (1968).

5. "Mass Spectrometric Studies of Plutonium Compounds at High Temperatures. IV. The Vaporization of Pux," by R.A. Kent and J.A. Leary, J. of High Temp. Sci., 1, 170 (1969).

6. "Thermodynamic Properties of Plutonitum Mononitride from Electronotive Force Measurements," G. M. Campbell and J.A. Leary, J. Phys. Chem. V. 70 , pp. 2703 to $2705(1966)$.

7. "Themodynamic Properties of Plutoritum Compounds by Elcetromolive Forcc Techniques, " G. M. Campbell, L. J. Mullins, and J. A. Leary, Thermodynamics of Nuclear Materials, 1967, International Atomic Energy Agency, Vicuna, (1968).

8. "Thermodynamic Properties of 1 MN by Galyanostatic Potential Determination," G. M. Campbell, Los Alamos Scientific Laboratory Report No. LA-3945, (1968).

9. "High-Temperature Heat Content and Heat Capacity of Uranium Dioxide and Uranium Dioxide-Plutonium Dioxide Solid Solutions," A. E. Ogard and J. A. Leary, Thermodynamics of Nuclear Materials, 1967, Inter. Atomic Energy Agency, Vienna (1968).

10. "Electrometallurgy of Plutonium," by J.A. I.eary and L. J. Mullins, ELECTROMFTALLURGY, edited by T.A. Henrie and D. H. Baker, Jr., Amer. Inst. Mining, Metallurgical, and Petroleum Engineers, Ir.c., 345 East 47 th St. , New York (1969).

11. "Temperature-Composition Diagl'ams of Pseudo-Binary System Containing Plutonium (III) Halides," J. A. Leary, comp., Los Alamos Scientific Laboratory Rcport No. I,A-2661 (1962).

12. "Temperature-Composition Diagrams for Binary Systems Containing Plutonium (II) Chloride," J.A. Leary, K. W. R. Johnson, and R. Benz, Presented at the XVIII International Congress of Pure and Applied Chemistry, Montreal, Canada (August 1961). 
13. "Parlial Phase Ijiagram of the $\mathrm{PuCl}_{3}-\mathrm{PuOCl}_{\mathrm{U}}$ System, " J. G. Reavis and J.A. L.eary, J. Inorg. Nucl. Chem., V. 28, pp 1205 to 1208 (1965).

14. "The Pu-PuCl ${ }_{3}$ System, " K. W. R. Johnson and J. A. Leary, J. Inorg. Nucl. Chem., 26, 103 (1964).

15. "The Solubilities of Caxbon, Tantalum, Tungsten and Rhenium in Liquid Plutonium, " D.F. Bower:ox and J.A. Leary, J. Nucl. Materials, 21, 219-224(1967).

16. "The Solubilities of Selected Elements in Liquid Plutonium Il. Titanium, Vandium, Chromium, Manganese, Zirconium, Niobilï, Molybdenum, and Thulium," D.F. Bowersox and J.A. Leary, J. of Nucl. Materials, $\underline{27}, 181-185(1968)$.

17. "Thermodynamics of Solution of Sclected Elements in Liquid Plutonium," D.F. Bowersox and J.A. Leary, J. of Nuclear Materials (in press).

18. "Thermodynamic Properties of Selected Solutes in Liquid Metal Solutions," D. F. Fowersox, 1969 Nuclear Metallurgy Symp., V. 15, "Reprocessing of Nuclear Fuels (in press).

19. "Practical Application of Thermodynamics to Plutonium Process Reactions at High Tempcrature, "J. A. Leary and L.J. Mullins, Symposium on Thermodynamics with Emphasis on Nuclear Materials and Atomic Transport in Solicls, Vienna (July 1965).

20. "Refined Plutonium-23s for Biomedical Applications, " L. J. Mullins and J. A. Leary, Trans. Amer. Nuclcar Soc., 11, 91-92 (1968).

21. "Plutonium-233 Materials as Radioisotopic Heat Sources for Human Vce," L. J. Mullins, G. M. Matlack, R. L. Nance, C. F. Metz, and J.A. Leary, American Nuclear Society Mitd., Seattle, Wash. (Junc 1969). 


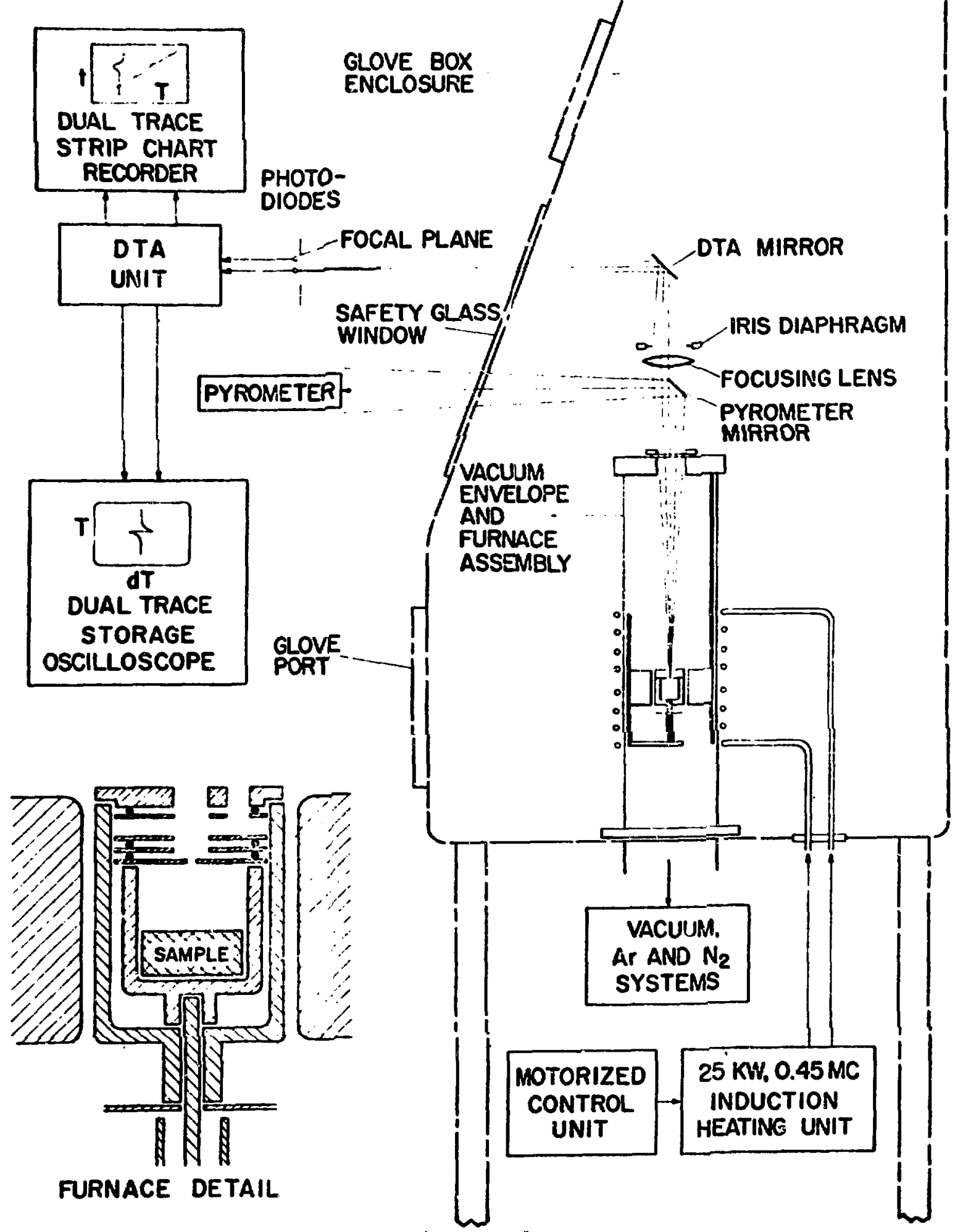

Figure 1. Differential Thermal Analysis Apparatus 


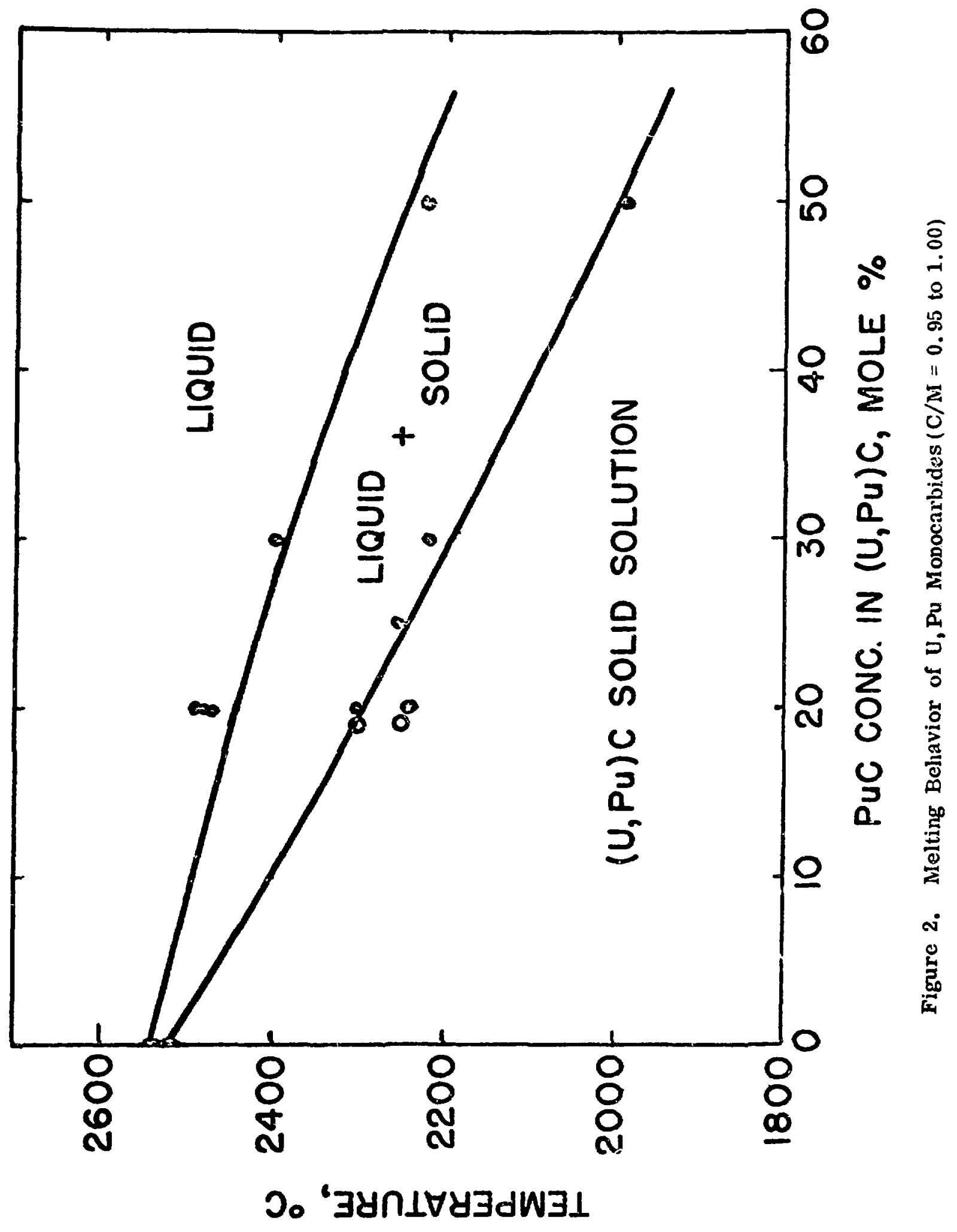




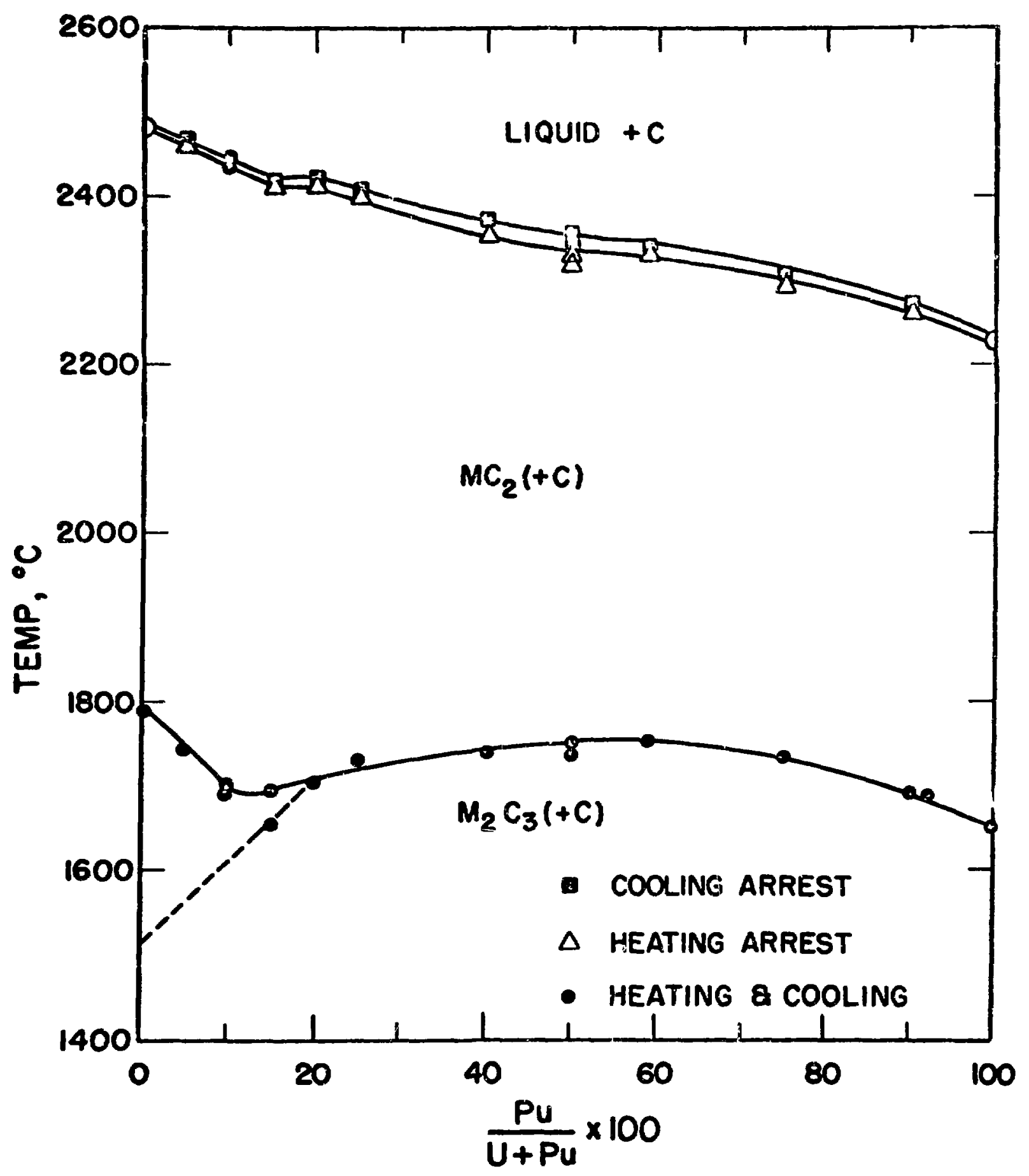

Figure 3. Thermal Arrests Observed for (U, Pu) Carbides Containing Ercess C 


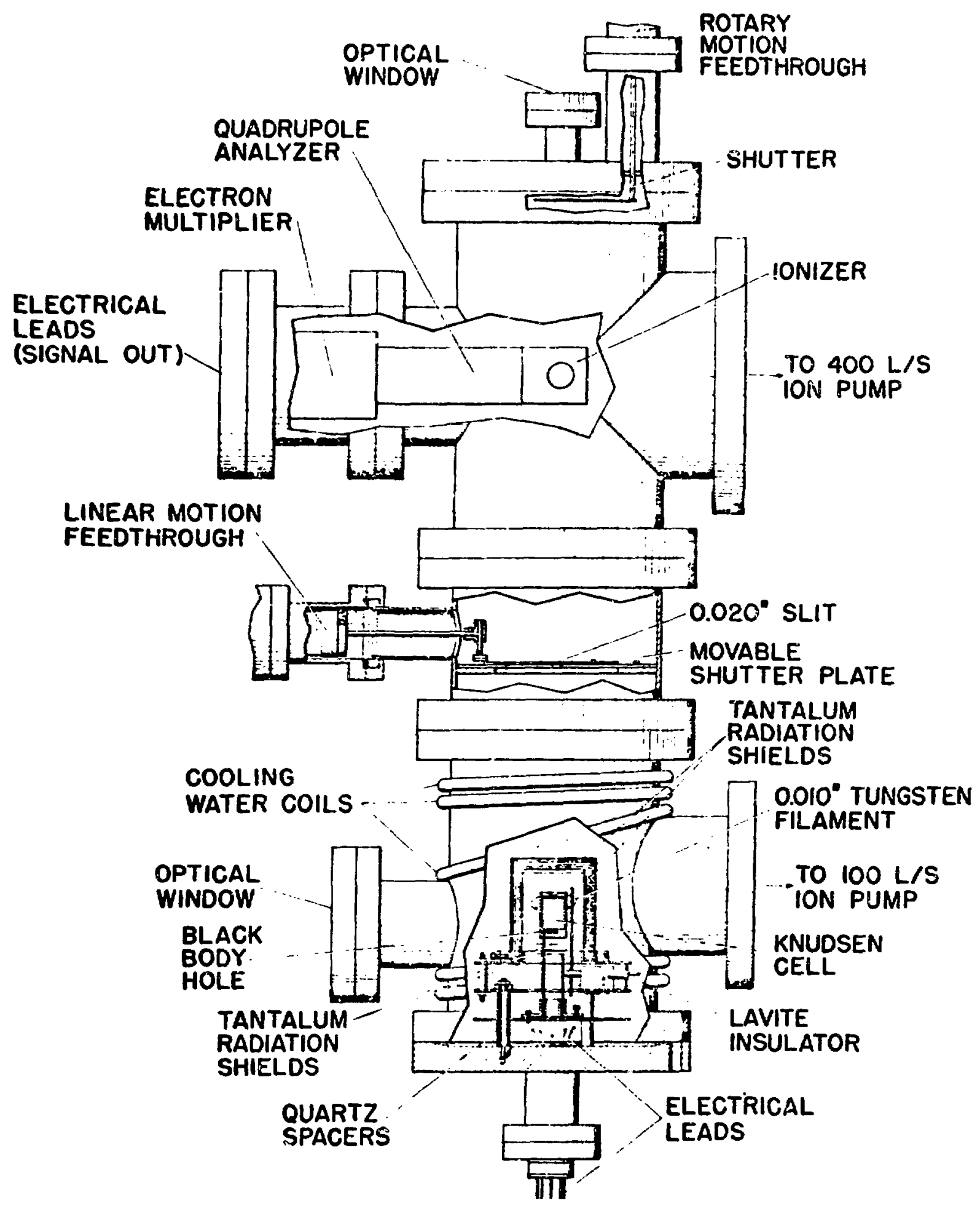

Figure 4. Mass Spectrometer - Knudsen Cell Assembly. 
$\mathrm{Pu}(\ell)=\mathrm{Pu}(\mathrm{g})$

$\log _{10} \mathrm{P}_{\mathrm{Pu}}(\mathrm{atm})=(4.924 \pm 0.120)-\frac{17420 \pm 184}{\mathrm{~T},{ }^{\mathrm{O}} \mathrm{K}}$

$\left(1426-1658^{\circ} \mathrm{K}\right)$

$\Delta \mathrm{H}_{\mathrm{V} 298}^{\mathrm{O}}=83.0 \pm 0.5 \mathrm{kcal} / \mathrm{mole}$

$\Delta \mathrm{S}_{\mathrm{V} 298}^{\mathrm{o}}=29.1 \pm 0.5 \mathrm{eu}$ 


\section{$\mathrm{PuF}_{3}(\mathrm{~s})=\mathrm{PuF}_{3}(\mathrm{~g})$}

$\log _{10} \mathrm{P}_{\mathrm{PuF}_{3}}=(9.288 \pm 0.087)-\frac{20734 \pm 118}{\mathrm{~T}, \mathrm{O}_{\mathrm{K}}}$

$\left(1243-1475^{\circ} \mathrm{K}\right)$

$\Delta \mathrm{H}_{298 \mathrm{sub}}^{\mathrm{O}}=101 \pm 3 \mathrm{kcal} / \mathrm{mole}$

$\Delta \mathrm{S}_{298 \mathrm{sub}}^{\mathrm{O}}=51.6 \pm 2.5 \mathrm{eu}$ 
$\mathrm{PuN}_{0.98}(\mathrm{~s})=\mathrm{Pu}(\mathrm{g})+0.49 \mathrm{~N}_{2}(\mathrm{~g})$

$\log _{10} \mathrm{P}_{\mathrm{Pu}}(\mathrm{atm})=(6.445 \pm 0.055)-\frac{21958 \pm 98}{\mathrm{~T},{ }_{\mathrm{K}}}$

$\left(1658-1976^{\circ} \mathrm{K}\right)$

$\operatorname{PuN}(\mathrm{s})$

$$
\begin{aligned}
& \Delta \mathrm{H}_{\mathrm{f} 298}^{\mathrm{o}}=-71.2 \pm 2.5 \mathrm{kcal} / \mathrm{mole} \\
& \Delta \mathrm{s}_{\mathrm{f} 298}^{o}=-19.9 \pm 2.0 \mathrm{eu}
\end{aligned}
$$




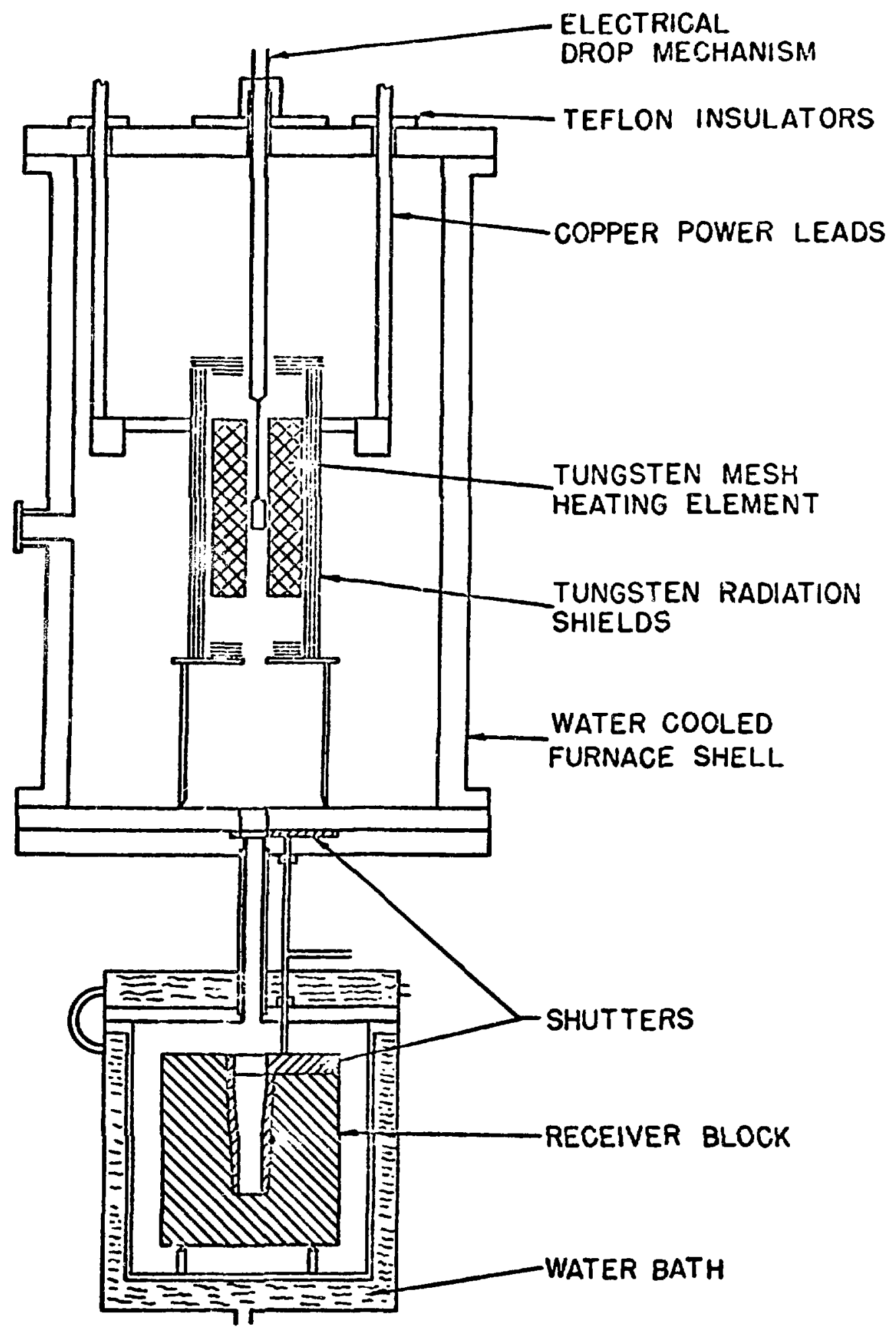

Figure 8. High Temperature Drop Calorimeter 


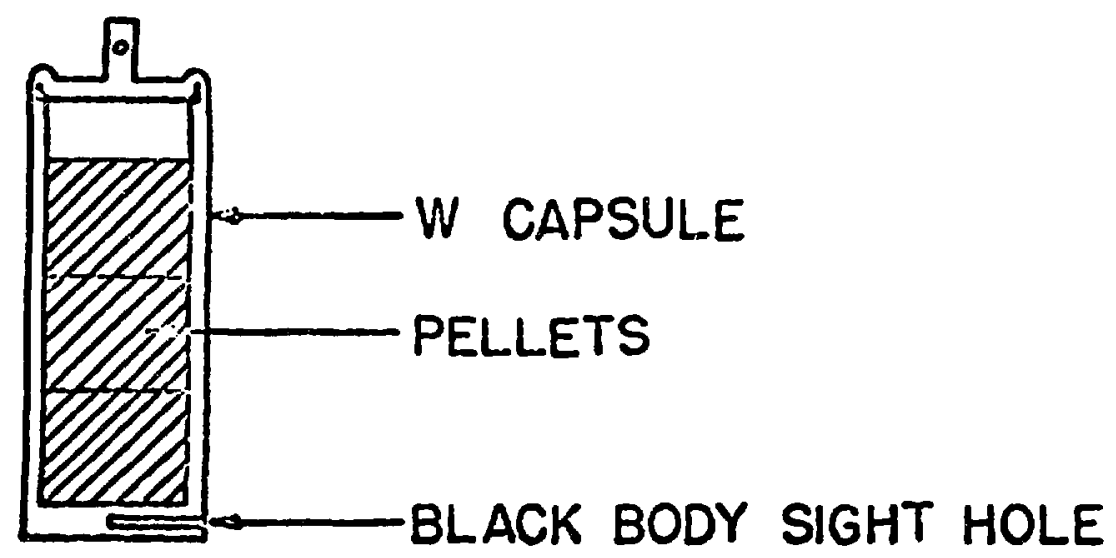

Figure 9. Tungsten Capsule for High Temperature Calorimetry 


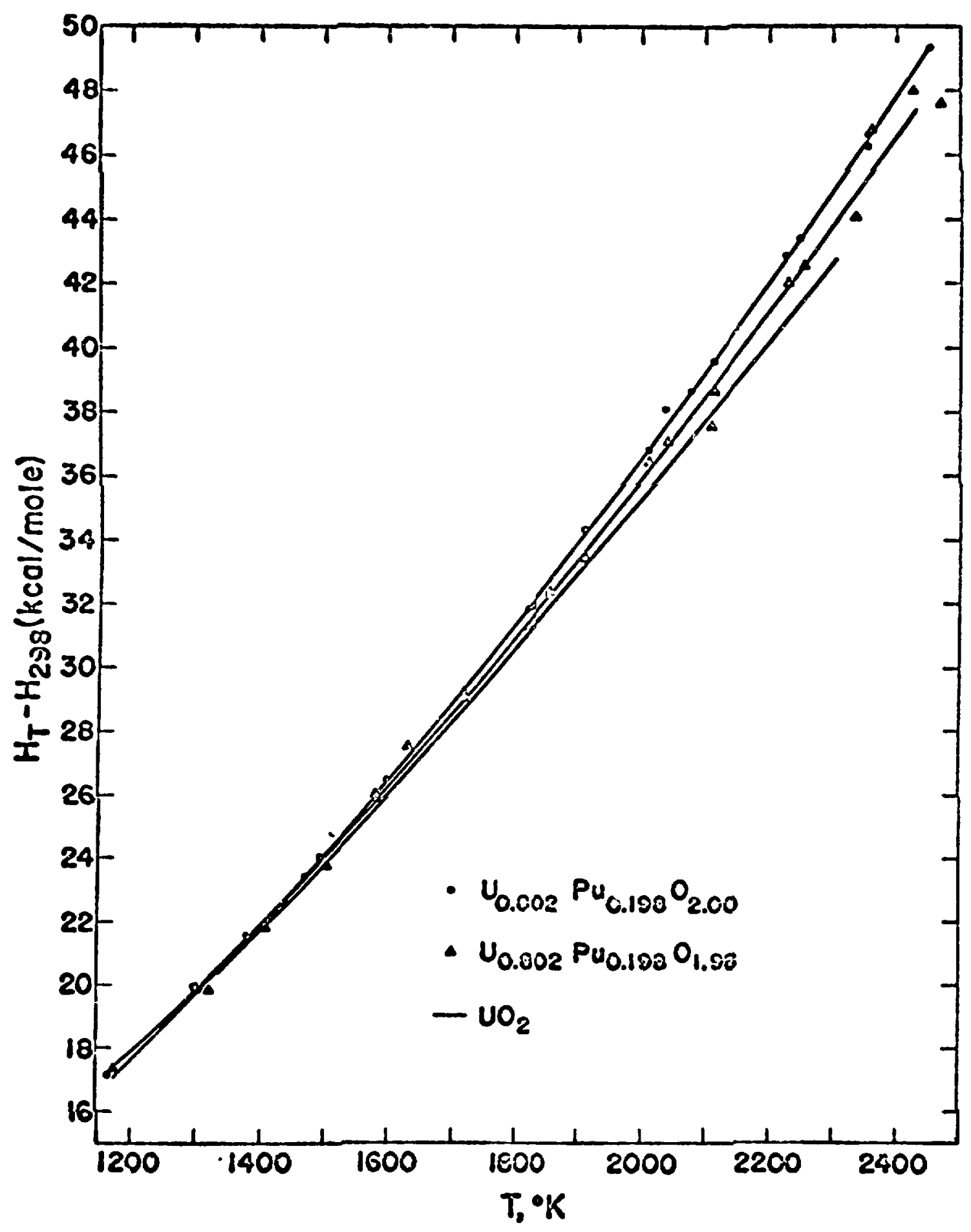

Figurc 10. Heat Contents of Various Oxides 